School of Finance

University of St.Gallen

EXPERIENCE AND BROKERAGE IN ASSET MARKETS:

EVIDENCE FROM ART AUCTIONS

BRUNELLA BRUNO

EMILIA GARCIA-APPENDINI

GIACOMO NOCERA

WORKING PAPERS ON FinANCE No. 2016/05

SWISS INSTITUTE OF BANKING AND FINANCE (S/BF - HSG)

FEBRUARY 2016 


\title{
Experience and brokerage in asset markets: Evidence from art auctions
}

\author{
Brunella Bruno* \\ Bocconi University, Department of Finance, Milan, Italy \\ Emilia Garcia-Appendini \\ University of St. Gallen, School of Finance, St. Gallen, Switzerland \\ Giacomo Nocera \\ Audencia Business School, Nantes, France
}

This draft: February 15, 2016

\begin{abstract}
Focusing on the art market, where auction houses act as brokers between art sellers and buyers, we investigate whether more experienced brokers achieve better performance as information providers. We use a unique data set of auctions of Italian paintings in various houses around the world, and we measure experience as the number of times an auctioneer has auctioned the artworks of a certain artist in a given location. We find that more experienced auction houses (i) are more likely to sell and (ii) provide more precise pre-sale estimates. These findings suggest that experience plays an important role for brokers to reduce illiquidity and opacity in markets with asymmetric information.
\end{abstract}

JEL Classification: G24, D44, D82, Z11.

Keywords: Brokerage, information, experience, art auctions.

\footnotetext{
* Corresponding author. Address: Bocconi University, via Röntgen 1, 20136 Milan, Italy; tel. +39 025836 5954; fax +390258365920.

E-mail addresses: brunella.bruno@unibocconi.it (B. Bruno), emilia.garcia@unisg.ch (E. GarciaAppendini), gnocera@audencia.com (G. Nocera).

We would like to thank Zeno Adams, Fabian Bocart, Martin Brown, Francesco Corielli, Anne Dempster, Carlo Favero, Roland Fuess, Debrah Meloso, Catherine Morel, Adriano Picinati di Torcello, Rachel Pownall Campbell, Carolyn Reichert, Christophe Spaenjers, Nandini Srivastava, and participants in seminars and conferences at Bocconi University, the University of St. Gallen, the 2013 Art Market Symposium (Maastricht University), and the 2014 Financial Management Association Meetings (Nashville) for helpful comments. All remaining errors are our own.
} 


\title{
Experience and brokerage in asset markets: Evidence from art auctions
}

\begin{abstract}
Focusing on the art market, where auction houses act as brokers between art sellers and buyers, we investigate whether more experienced brokers achieve better performance as information providers. We use a unique data set of auctions of Italian paintings in various houses around the world, and we measure experience as the number of times an auctioneer has auctioned the artworks of a certain artist in a given location. We find that more experienced auction houses (i) are more likely to sell and (ii) provide more precise pre-sale estimates. These findings suggest that experience plays an important role for brokers to reduce illiquidity and opacity in markets with asymmetric information.
\end{abstract}

JEL Classification: G24, D44, D82, Z11.

Keywords: Brokerage, information, experience, art auctions. 


\section{Introduction}

For activities as varied as choosing an investment fund, purchasing a house, and buying or selling a piece of art, individuals usually rely on the advice and services of brokers. In exchange for a fee, these intermediaries mitigate information asymmetries and bring together transactors with complementary needs. According to theory, brokers develop special skills in interpreting subtle (that is, not readily observable) signals related to the deal, and therefore they are a cost-efficient solution to problems of asymmetric information. This is because they are able to avoid the duplication of information production and can spread the costs of information production over several clients and through time (Ramakrishnan and Thakor, 1984; Millon and Thakor, 1985; Bhattacharya and Thakor, 1993).

In this paper we analyze whether more experienced brokers achieve a better performance as information providers. We focus on the art market, a brokered market with severe illiquidity and acute information asymmetry problems (Baumol, 1986). In this market, auction houses act as "information brokers” à la Ramakrishnan and Thakor (1984) or “information gathering agencies" à la Millon and Thakor (1985), i.e., they are intermediaries who acquire and process information on behalf of the transacting parties, and whose compensation depends on how well they perform their task. Through these activities, brokers facilitate matching in a market in which it is difficult for buyers and sellers to meet on their own (Biglaiser, 1993).

We find that experienced art brokers perform better than less experienced intermediaries. Because brokers' output is often an intangible service whose reliability is not directly observable (Ramakrishnan and Thakor, 1984), we measure art brokers' performance using two proxies. First, we measure art brokers' ability in bringing together supply and demand by considering an auction house's likelihood of a sale. Second, we assess the auction houses' performance in producing information on the basis of how well their predictions did relative to events observed after the predictions (Ramakrishnan and Thakor, 1984). Specifically, we look at the distance between the estimated price of the artwork before the sale and the actual price fetched at the auction. 
Our measure of art broker's experience depends on the number of times that the auction house has auctioned the paintings of a given artist in the past. Because experience is the result of the accumulation of past information and such information is reusable, an increase in experience should induce an increase in the available input for brokers. An increased experience should also expand brokers' expertise and skills and improve their production process as a whole (Biglaiser, 1993). We therefore expect more experienced art brokers to perform better than less experienced ones. In fact, our findings show that (i) brokers are more likely to achieve a sale for a painting of an artist that they put up for auction frequently and (ii) they are more accurate at predicting the prices fetched at auctions through their pre-sale estimates.

To gauge the causal effect of experience on auction outcomes, we use a large sample of auctions of paintings by Italian artists held in numerous fine art auction houses around the world, and we follow an identification strategy similar to the one in Khwaja and Mian (2008) which has become popular in the literature of financial intermediation. In our setting, the methodology consists of introducing different sets of interacted fixed effects at the artist, auction house, location, and/or year level, to control for time-varying unobserved differences in the composition in demand and supply for different artists in different houses. This approach allows us to compare closer counterfactuals. For example, it enables us to compare the sale rates for artists for whom a given auction house has a large experience, with sale rates for artists in the same house, town, and year, for whom the auction house has a lower experience.

In contexts with high information asymmetries, such as the venture capital (see Gompers et al., 2008), the securities underwriting (Benveniste et al. 2002), and the M\&A advisory industry (Chang et al., 2015), industry-specific experience tends to be more important than the general experience. Consistently, we define experience at the artist level because the art market is highly fragmented and there might be a great variety in the quality and value of art within the same collecting category and even within an artist's production. Collectors also tend to specialize in small groups of painters and their typical portfolios of paintings are characterized by a low degree of diversification. 
Also, in brokered markets the relevant information is often qualitative, relationshipbased, and soft, ${ }^{1}$ and can normally be obtained through proximity and personal interaction with market participants. ${ }^{2}$ During IPO transactions, for example, underwriters enhance their accuracy in pricing the issue evaluation through their relationships with the investors invited to participate to the bookbuilding process. During this process, they gather information from investors who provide them with preliminary indications of the demand for the issue (Benveniste and Spindt, 1989; Spatt and Srivastava, 1991). Networking and proximity to the client are also relevant sources of privileged information for art brokers (Bonus and Ronte, 1997) and previous auctions provide auction houses with a unique opportunity to connect with art market participants and acquire private information about supply and demand factors that may affect a given artist's works. This type of information, although reusable, may be hard to transfer across locations - even within the same auction house. To address this issue and better capture the advantage of proximity and networking, we measure experience at the local level, i.e. for a given showroom of an auction house. This means, for example, that an auction in the London showroom of a given auction house will only count towards experience for the showroom in London, but it will not count towards experience for that auction house's rooms in New York or elsewhere.

To the best of our knowledge, this is the first paper to document that experience plays a role in improving information brokers' performance. In that, it contributes to the literature on the role of brokers in reducing information asymmetries (e.g., Ramakrishnan and Thakor, 1984; Biglaiser, 1993) and, more generally, to the literature on information production by intermediaries and the role of differential information among intermediaries (see Hauswald and Marquez (2006), among others).

Our findings also expand the literature on auctions by showing that auction outcomes can differ according to the characteristics of the auctioneers. In this respect, our results are most related to those of Lacetera et al. (2013), who find that auctioneers' personal traits can affect auction outcomes. Differently to their study, we focus on the

\footnotetext{
${ }^{1}$ Petersen (2004) contains a definition and discussion of the differences between hard and soft information.

${ }^{2}$ The relevance of collecting client-specific information and the role of human intensive and qualitative information are well documented in the related literature. See Berger and Udell (1995), Ongena and Smith (2001), Petersen and Rajan (2002), Stein (2002), and Agarwal and Hauswald (2010), among others.
} 
auctioneer's experience rather than on other subjective personal traits. Finally, our paper provides new evidence to the specialized literature on economics of art and the value of brokers in affecting art auctions' results (e.g., Ashenfelter, 1989; Bauwens and Ginsburg, 2000; McAndrew et al., 2012).

The paper is organized as follows. Section 2 describes the institutional background of art market auctions and clarifies the relevance of auction houses' experience. Section 3 discusses the data sources, summarizes the sample characteristics, and describes our identification strategy. Section 4 presents our main empirical analysis and some extensions. Finally, Section 5 concludes the paper.

\section{Institutional background: Art brokers as information producers}

Art sales are roughly equally split between two main types of intermediaries: dealers and auction houses acting as brokers (McAndrew, 2010). Given the objectives of this study, our focus is placed on the latter. The auction segment is highly concentrated, with Sotheby's and Christie's accounting for about one third of the total auction market share by value. There is an important second tier of auction houses with international relevance (e.g., Bonhams \& Butterfields or Phillips) and a third tier of smaller auction houses of national scope that tend to specialize in domestic art. Larger auction houses generally conduct auctions on the full spectrum of collecting categories and are organized in different departments, with experts who are highly specialized in certain genres, market segments, or geographical markets (McAndrew, 2010).

Auction houses charge both buyers and sellers for their services. The commission charged to the winning bidder, called the buyer's premium, is generally between 10 and 20 percent of the hammer price. Depending on the auction house, the seller's commission can be either a flat rate (typically 10\%), or determined by a sliding scale which varies according to the volumes and values of sellers' transactions over a period. The seller's commissions are often negotiated (Ashenfelter and Graddy, 2003) and, in some cases (e.g., for big vendors), auction houses waive the seller's fee as a way to attract the best 
vendors or pieces of art in a highly competitive market. ${ }^{3}$ In case the artwork goes unsold at the auction (i.e., it is "bought-in"), certain charges may still apply (for example, shipping and handling costs), and in such a case the seller's reserve price, i.e. the lowest price at which the seller is willing to sell the work, is used to determine these fees. The reserve price is often discussed and negotiated with the seller prior to the auction, and it is never disclosed to the public (Ashenfelter and Graddy, 2003).

As qualified experts in the sector, auction houses produce informed estimates of future prices, which are published in auction catalogs prior to an auction. Pre-sale estimates were first introduced in the mid-1970s with the purpose of attracting individual investors and level the playing field between experienced wholesale participants and uninformed retail customers (Mei and Moses, 2005). According to Sotheby's, an auction estimate is "a price that the auction house's specialists believe a piece might bring at auction.” Since the price of an artwork is hard to predict, estimates are usually expressed as a range. Auction houses commonly observe an unwritten rule of setting the low estimate of this range at or below the secret reserve price (Ashenfelter and Graddy, 2003). Setting accurate estimates requires great expertise in artistic factors and knowledge of market trends. Most of this knowledge is acquired through frequent contacts that art brokers hold with their clients.

There are several occasions for art brokers to build client relationships and acquire privileged information on, for example, bidders' preferences, holdings, and expenditure capacity, or sellers' expectations and financial needs. First, art auctions are commonly preceded by private events organized by auction houses, such as cocktail parties and auction previews. The main objectives of these events are to foster the relationship with art investors and collectors, create an exclusive network, and favor the exchange of informal communication that may help understand art sellers' and bidders' preferences. ${ }^{4}$ Mutatis mutandis, these gatherings are not dissimilar from the bookbuilding procedure, a mechanism that allows the investment banker to extract information from investors which

\footnotetext{
${ }^{3}$ See, for example, the article “The (auction) house doesn’t always win,” The New York Times, January 15, 2014.

${ }^{4}$ Velthuis (2011a) acknowledges the social reason among the different motives for buying a work of art: Buying art is sometimes a sort of ticket to a social circle, such as a group of collectors who buy at the same art gallery and meet at art world events. Familiarity with these circles is crucial to estimating the demand of the artworks of certain artists or collecting categories.
} 
will be helpful in pricing the issue accurately (Benveniste and Spindt, 1989; Spatt and Srivastava, 1991). ${ }^{5}$

Privileged information is also generated during the auction, regardless of whether the painting ends up being sold or bought in. Auction houses know the identity and bids of all interested buyers, including those placing bids through the phone or electronically information that is not available to other auction participants. More generally, the bidding process is informative per se, since bidders' behaviors in the auction room (e.g., how they react to various lots) can convey to the auctioneer valuable information about art buyers' preferences. For the above reasons, we expect that a greater conversancy with sellers and bidders results in an information advantage for the art brokers that develops over time.

In this study we use the auction house's previous experience auctioning items of a given artist as an indirect measure of the value of the privileged information acquired through frequent contact with market participants. ${ }^{6}$ With this measure we intend to capture the degree of closeness of the relationship of the intermediaries with the market participants, in the spirit of Uzzi and Gillespie (2002). As occurs in an IPO, the relationships that matter in our setting are those with participants in both the sides of the market: issuers and investors in the IPOs, sellers and buyers in the art market. It is important to highlight that, in our view, the information advantage held by experienced auction houses goes beyond the knowledge of past prices or auction outcomes, since this sort of information can be obtained, at least in principle, by any market participant. ${ }^{7}$ Rather, we are interested in the type of experience that refers to the ability to interpret the subtle signals provided by market participants prior to and during the auctions, in the spirit of Bhattacharya and Thakor (1993).

Our main hypothesis is that through frequent past auctions, experienced auction houses have accumulated more information about the market dynamics of a given artist than less experienced brokers. Therefore, they should be better able to favor demand to meet supply and to set more precise pre-auction price estimates.

\footnotetext{
${ }^{5}$ An initial issue is usually preceded by a phase of informal communication between the investment banker and the prospective underwriters prior to the allocational stage of the offering.

${ }^{6}$ We measure experience as the number of times that the auction house put up works of the artist for auction. In the data description section we provide a more precise definition of this variable.

${ }^{7}$ Online databases of auction records, artists' catalogs, and art historical publications have improved information availability in the market.
} 
Experienced auctioneers could exploit their superior information in several ways in order to achieve more precision of the estimates and higher likelihood of sale. First of all, they could highlight the features of the artworks that are most appealing to buyers, thus widening the base of potentially interested buyers. They could also advise overoptimistic sellers to lower their reservation price for artworks where demand is relatively low.

Experienced auctioneers could also exploit their more extended relationship network to help reduce search frictions and match the artworks in offer to the most suitable buyers. Finally, experienced auction houses could also realize actions during the auction itself to increase the likelihood of a sale, such as setting the starting bid price, changing the pace of price adjustment, or by placing fictitious "off the wall" bids. See Ashenfelter (1989), Vincent (1995), or especially Lacetera et al. (2013) for more examples on how auctioneers could affect auction outcomes.

\section{Data, variables, and identification strategy}

\subsection{Data sources and sample characteristics}

Our base data set consists of all Italian paintings auctioned in the salerooms of 33 auction houses all over the world from 1990 to 2008, as provided by Art Index-Munus database. The raw data set contains 98,844 observations, corresponding to the auctions of around 87,000 unique paintings of about 5,000 Italian artists belonging to one of three collecting categories: Old Masters, $19^{\text {th }}$ Century (i.e., Modern art), and $20^{\text {th }}$ Century (i.e., Contemporary art). We remove from the data set all paintings with a high price estimate lower than US\$1,000, as well as auction houses focusing on minor artworks and those that do not provide pre-sales estimation ranges. We use the first 10 years of observations from the raw sample to construct our main variable of interest, experience (see the next paragraph), and eliminate these observations from our estimation sample to avoid left censoring of the data. Our analysis is thus focused on the remaining observations, corresponding to years 2000 to 2008. The resulting sample consists of 49,573 observations, corresponding to 47,042 unique paintings of 2,543 artists, auctioned by 23 auction houses in 29 towns in 13 countries. Around half of the paintings in our sample (48.6 percent) belong to the Old Masters collecting category; 18.4 percent belong to the $19^{\text {th }}$ Century category, and the remaining 33 percent to the $20^{\text {th }}$ Century category. The 
majority of the paintings in our sample were auctioned in Italy (57.7 percent), followed by the United Kingdom (22.6 percent) and the United States (7.8 percent). Most of the auctions were held at Sotheby's (25.3 percent), Christie’s (23.3 percent), or the Italian auction house Finarte-Semenzato (25.5 percent). 29,039 paintings were sold, corresponding to 58.6 percent of all paintings put up for auction in our sample. Table 1 reports more details on the distribution of these observations according to artwork category, auction house, location, and year of the auction.

\section{Insert Table 1 approximately here}

\subsection{Experience}

We define our key explanatory variable (experience) in relative terms, as the number of paintings of the artist that have been auctioned in the auction house and town during the $T$ years preceding the current auction, divided by the total number of times that the artist has been auctioned in any auction house during the same period. In tests of robustness, we also measure the auction house experience in absolute terms using the variable absolute experience, defined as the number of paintings of the artist that have been auctioned in the auction house and town during the previous $T$ years. We can define several experience measures allowing the time horizon $T$ to vary from one to 10 . In our main analyses, we set the time horizon to $T=5$. In Section 4.3 we show that results are qualitatively similar for the 10 different measures of experience obtained by allowing the time horizon $T$ to vary from one to 10 years. Notice that we require $T$ years of observations prior to each auction to calculate the experience variables. Thus, the first $T$ years of information in our sample are only used to construct our experience variables, but cannot be included in our main analysis since we do not have enough information to construct the experience variables for these observations. To make our estimation sample comparable across the 10 different measures of experience resulting from changing the time horizon, and at a cost of a smaller sample, for all estimations involving different time horizons $T=1,2, \ldots, 10$, we discard the period 1990 to 1999 using it only as a 
reference period to calculate the experience variables, and we perform our main analyses using only the observations from 2000 to $2008 .^{8}$

Our experience dimension is evaluated at the auction house and town level. This means that we implicitly assume that the experience for a given artist at, say, Christie's in London can differ from that in Milan, New York, or any other Christie's saleroom in our database. This assumption is motivated by the fact that the art market exhibits strong local features (Velthuis, 2013). For example, the average Western art dealer has a local clientele and predominantly represents artists of the same nationality. This observation is confirmed for our sample in Table 1, as more than half of the sales occur in Italy. Therefore, the auctioneer's experience we refer to reflects not only a possibly superior knowledge of the author's artistic production (which could be easily transferred from one saleroom to another) but also some acquaintance and proximity with the potential buyers and sellers, which is much more specific to a given location. We believe that ties across market participants, and therefore the flows of information between them, are stronger at a local level, especially in markets such as the one in our sample, where most pieces of art are traded domestically.

Table 2 contains a simplified example of the variation captured by our experience variable. The columns contain examples of nine different artists in our sample: Canaletto, Luca Giordano, and Tiziano (Old Masters), Beppe Ciardi, Vincenzo Irolli, and Attilio Pratella (19 $9^{\text {th }}$ Century artists), and Tano Festa, Lucio Fontana, and Mario Sironi (20 $0^{\text {th }}$ Century artists). The rows contain all the different combinations of auction houses and towns that auctioned at least one of the paintings of these artists during the period 2000 to 2008. Each cell contains the average value of variable experience for each auction house when it auctioned the paintings of each of these artists. For example, the London salesroom of Bonhams and Butterfields had an average experience on Luca Giordano of 0.039. This means that during the five years previous to each auction of a painting of Luca Giordano, Bonhams and Butterfields auctioned, on average, 3.9 percent of all of this

\footnotetext{
${ }^{8}$ This approach can raise the concern that we are throwing away information in the estimations in which experience is measured in horizons shorter than 10 years. To address this concern, in a robustness analysis we expand the number of observations in the estimations of horizons shorter than 10 years. Specifically, we use samples from 1991 to 2008 for our one-year horizon estimations (using year 1990 to construct the experience variables), from 1992 to 2008 for the two-year horizon estimations (using 1990 and 1991 for the experience variables), and so forth. The results do not vary due to changes in the sample composition for the different time horizons.
} 
artists' paintings. In contrast, Christie's London auctioned on average 16.8 percent of all of Giordano's paintings during the five-year period previous to his auctions, Christie's New York 8.4 percent, and Finarte-Semenzato Goito (Mantua) none. ${ }^{9}$

In the same fashion, we can observe that Dorotheum Vienna has a moderate experience with the Old Masters artists in our example, having held on average 6.2 percent of all auctions of paintings by Canaletto, 4 percent of Luca Giordano's, and 13 percent of Tiziano's. On the other hand, Dorotheum Vienna put on sale the $19^{\text {th }}$ century artists' works (Attilio Pratella and Vincenzo Irolli) having no previous experience dealing with these artists in the 5 years previous to the auctions.

Finally, we can observe that there are many auction house-town combinations that did not auction paintings by some of these artists during the sample period. For example, out of these nine artists, Bruun Rasmussen Copenhagen only auctioned paintings by Tiziano. In contrast, Christie’s London and Sotheby's Milan auctioned paintings by each of these nine artists. As can be seen from these simple examples, our sample contains significant cross-sectional variation both across different auction houses for a given artist, and across artists within each auction house. As shall be seen in Section 3.4, we will exploit these different sources of variation for our identification strategy.

\section{Insert Table 2 approximately here}

\subsection{Dependent variables}

Because brokers offer an intangible service whose reliability is not directly observable (Ramakrishnan and Thakor, 1984), we assess whether more experienced auction houses achieve better performance using two different dependent variables as proxies: (i) a binary variable taking the value of one if the painting was sold at the observed auction and zero otherwise (sold), and (ii) the absolute value of the difference between the midpoint of the estimation range and the hammer price, divided by the hammer price (distance).

\footnotetext{
${ }^{9}$ Notice that for a given artist, the sum over all auction houses of the average values of experience over the previous $T$ years does not have to sum to one. This is because auctions of the same artist occur at different points in time in different auction houses. Moreover, the reported figures are the average values of experience of all paintings of a given artist in a given auction house during the whole sample period.
} 
The former, sold, measures the broker's ability to facilitate a matching in a market in which it is difficult for buyers and sellers to meet on their own (Biglaiser, 1993), and it is equivalent to the "conversion rate" used in Lacetera et al. (2013). This variable determines whether the auction house achieved its ultimate goal of selling the items at auction.

The second variable, distance, is a measure of the precision of the estimates in the intensive margin; that is, it is defined only for the subsample of paintings that were sold. This variable gives us a continuous measure of how far the price estimate is from the actual fetched price. Indeed, the main piece of information the auction house provides prior to an auction is the estimated price of the item. The theoretical literature suggests that the auction house's best strategy is to provide truthful information about the item being sold (Milgrom and Weber, 1982). Supporting the theoretical literature, Ashenfelter (1989) suggests that auction houses make an effort to estimate the price an item will fetch.

\subsection{Identification strategy}

Our main goal in this paper is to assess whether there is a causal effect of experience on auction outcomes. For this purposes, we start with the following reference regression model:

$$
y_{i j t}=\beta_{0}+\beta_{1} \text { experience }_{j t}+\beta_{2}{ }^{\prime} X_{i j t}+\gamma_{c}+\delta_{h}+\lambda_{l}+\eta_{t}+u_{i j t}
$$

where $y_{i j t}$ refers to the two dependent variables measuring the outcomes of the auction run by the auction house $j$ of painting $i$ at time $t$ (sold and distance); $X_{i j t}$ is a vector containing observable control variables which affect auction outcomes and could be correlated with experience, such as the auction house's market share or the novelty of the artwork auctioned; ${ }^{10} \gamma_{c}, \delta_{h}, \lambda_{l}$, and $\eta_{t}$ are fixed effects for the artist's category, the auction house, the auction location, and the year of the auction, respectively; and $u_{i j t}$ is the error term.

The above model specification (specification $I$ ) poses a basic identification problem, as there could be several omitted factors which are unobservable to the econometrician but available to auction houses, bidders, and/or sellers, that could drive

\footnotetext{
${ }^{10}$ See Section 3.5 for the complete list of controls and their precise definition.
} 
the observed relation between our experience variable and the different outcomes. For example, it is possible that investors interested in purchasing paintings of certain artists are geographically concentrated or prefer certain locations for the purchase. In this case, auction houses operating in these areas will have more frequent auctions for these artists, and will exhibit higher likelihoods of sale, for reasons other than experience. Similarly, sellers of paintings of certain artists could participate in houses which are frequented by more "credulous" investors, as defined by Mei and Moses (2005). Hence, these investors would bid closer to the estimated prices, thus increasing the probability of a sale, and the coefficient for experience would capture these relations.

To mitigate these endogeneity concerns, we follow an identification strategy similar to Khwaja and Mian (2008). The methodology in our setting consists of saturating the above regression model with several sets of interacted fixed effects to control for differences in the composition in demand or supply for different artists in different houses.

To begin with, we add one fixed effect for each combination of auction house, auction town, and year. This specification (specification II) controls for a potential selection of certain types of buyers into certain auction locations (i.e., auction house and town combinations), and compares auctions of paintings by artists for which the same auction house in a given town has different degrees of experience. Going back to our example in Table 2, in this specification we compare auction outcomes held within Finarte-Semenzato in Rome in a given year, for artists such as Mario Sironi or Lucio Fontana, for which this house has relatively little experience, with outcomes of an artist such as Tano Festa, who has been featured in several auctions at Finarte Semenzato in Rome. Further, the interaction with the auction year controls for trends in the art market and ensures that the comparison is done for auctions held in the same venue during the same year. In this way we exploit the heterogeneity of experience within each venue and year for different artists. The artwork category fixed effects further control for the differences in collectors' tastes.

Specification II controls for differences in the composition of investors (demand) and sellers (supply) across different auction houses, towns, and years, as well as for differences across the artwork categories. However, it does not account for differences 
across artists. Therefore, in a further specification (specification III) we substitute the auction house-town-year fixed effects with artist fixed effects. These fixed effects allow us to compare outcomes of auctions of the same artist that were held in auction houses with different degrees of experience. We believe that this specification is the most relevant for our research question, since it exploits the cross-sectional heterogeneity in experience for the same artist between different auction houses as shown in Table 2. By keeping the artist fixed, we control for differences in the composition of sellers, collectors and/or investors supplying or demanding paintings of different artists. In our example, we would be comparing auctions in one fixed column across the different rows. For example, we compare auctions of Tiziano's paintings in houses such as Dorotheum Vienna or Sotheby's London (which are relatively experienced in this artist's works) with auctions in Bonhams and Butterfields London or Lempertz Cologne (which have not frequently dealt with Tiziano), and with auctions in Christie's London (which is the most experienced house for Tiziano's paintings). In these specifications, the inclusion of separate auction house and auction town fixed effects controls for omitted factors that are fixed within auction houses or towns during our sample period. We also include auction year fixed effects to control for good or bad years in the art market.

While the previous specification allows for general trends in the art market, it has the disadvantage that it does not take into account trends for a given artist. It is well known that artists go in and out of fashion throughout time and that a "stylistic risk" may occur, as it happens, for example, with artworks and artists that become worthless after their first auction sales (Goetzmann, 1993). Thus, the previous specification risks comparing artists during their peak periods, where auction houses are more likely to sell and the investors' estimates are more likely to be correlated, with years in which artists have little attention from the market, buy-in rates are higher, and prices are more difficult to estimate. To take into account these trends, we further interact each artist fixed effect with the year of the auction, so that comparisons are done across the auction houses that have auctioned the same artist during the same year. This model (specification IV) effectively imposes a restriction in the data structure, as it requires that there are at least two auctions of paintings of the same artist occurring in the same year. Moreover, the 
separate inclusion of auction house and auction town fixed effects control for omitted factors that are fixed within auction houses or towns during our sample period.

At a cost of an even more restrictive model, we enhance the estimations with artist times years fixed effects by interacting the artist not only with the year fixed effect, but also with the town in which the auctions take place. This specification (specification $V$ ) controls for the fact that investors in different towns could have different tastes (even within a same year) and hence, auction houses in different towns for a given artist could have very different measures of experience. For example, as we can see in Table 2, artists with an international reputation such as Canaletto or Lucio Fontana appear relatively often in international auction houses (in particular, in London), whereas more local artists such as Tano Festa or Attilio Pratella appear relatively more often in auction houses in Italy and, in particular, in Milan or Rome. Therefore, with this specification, Fontana's auctions in a given year in Sotheby's London will be compared with those auctions during the same year in Christie's London and in Phillips London, whereas Festa's auctions in Christie's Milan will be compared with those in Pandolfini, FinarteSemenzato, Porro, and Sotheby's in Milan, and so on. This specification has the advantage that it takes into account the heterogeneity in investors' tastes for different artists across different towns and countries, while comparing the outcome results across auction houses with different degrees of experience. On the other hand, it imposes larger data restrictions than the previous model, since the estimation requires at least two auctions of paintings of the same artist in the same town and year. Moreover, in the case of regressions for the distance between the price and the midpoint of the estimation range, we require at least two sales of paintings of the same artist in the same town and year, an even tighter constraint. As before, the specification separately includes auction house fixed effects to control for differences across different auction houses that are fixed during our observation period.

Finally, we estimate a model that includes interacted fixed effects for artist, auction house, and auction town, and separately includes year fixed effects to control for general trends in the art market. This specification (specification VI) exploits the variation in experience over time within a given auction venue for the same artist. The advantage of this specification is that, by keeping the house, town, and artist fixed, we control for 
differences in artists that sell in a given auction house, as well as for differences in auction houses selling a given artist. However, the model also imposes some restrictions in the data structure, since it requires at least two auctions of the same artist in the same auction house and town in our sample.

\subsection{Control variables}

In all the above specifications ( $I$ to $V I$ ), we also control for other factors that may influence auction outcomes and which could be correlated with the auction house's experience. The first such control, artist visibility, measures the artist's presence in auctions and is defined as the number of times that the artist's works have been auctioned in any auction house during the time horizon $T$. This variable takes into account that there may be more overall information available about an artist that frequently appears in auctions, and it accounts for potential trends for a given artist. We also add a quadratic term of this variable to capture a potentially non-linear relation between the artist's presence at auction and the auction outcomes.

Additionally, we control for the estimation range (multiple), which is defined as the ratio of the maximum value of the pre-sale price range estimate to the minimum value of the pre-sale estimate range. Intuitively, a wider range (hence, a higher multiple) should signal a higher degree of uncertainty around the true value of the painting.

One could be concerned that our measure of experience captures the market power or the reputation of larger auction houses, which are able to put up for auction a wider portfolio of artists and a larger number of paintings and are hence generally more experienced. If bidders are more “credulous” (Mei and Moses, 2005), that is, more likely to believe the estimates of top-tier auction houses relative to smaller firms, the observed results could simply be a consequence of the higher market shares of certain houses. To deal with this issue, we control for the market share at the auction house, location, and year level (market share) by calculating the ratio of total sales in each house, town, and year and dividing it by the total sales over all auction houses during the same year.

We also control for the fact that it might be easier to evaluate and exchange artworks that have recently appeared in auctions, compared to items that appear for the first time in a long period. When an artwork has been recently auctioned, there is recent 
public information about its demand and supply that could make it easier to find consensus among its value in a second auction. In fact, Beggs and Graddy (2009) find that a recent price can be used as an anchor for the value of bids in the following auction. On the other hand, there could be more uncertainty in the value of a piece of art that is auctioned for the first time in a long time. To control for this, we introduce a dummy variable (first auction) that takes the value of one when the observation corresponds to the first auction of a given artwork in our sample (i.e., the artwork has not been auctioned since 1990) and zero otherwise.

Finally, as shown by Equation (1), we also control for unobserved variables that are constant within houses, locations, and collection categories throughout the observation period and which could be correlated with our variable of interest (e.g., the composition of demand). For this purpose, we include a separate set of fixed effects for each of the auction houses, locations, and artwork categories, as well as year fixed effects to capture secular trends in the demand and supply of artworks through the business cycle. Of course, the estimation of some of these coefficients will not be possible in specifications $I I-V I$, as their effects will be subsumed with the interacted fixed effects.

\section{Empirical analysis}

\subsection{Summary statistics}

Before we report the results of the main regression models, in Table 3 we present some key summary statistics of the relative and absolute experience variables, the dependent variables, and the control variables. Unless we explicitly state otherwise, in all analyses that follow we use a time horizon of $T=5$ to calculate the experience variables and the artist visibility.

The first three columns of Table 3 show the mean, the median, and the standard deviation for all the paintings in our sample. From absolute experience, we can observe that a given auction house hosts, on average, six to seven auctions with the paintings of a given artist each 5 years, out of an average of around 45 auctions per artist across all the different auction houses and locations (as measured by the variable artist visibility). The average value of experience is around 17 percent. This means that roughly one out of six 
auctions of the same artist are held in the same auction house and location. Given the large number of auction houses and artists in our sample, this number indicates a significant degree of specialization of auction houses in certain artists.

In columns 4 to 7 we split the sample into paintings auctioned by auction houses that exhibited a low experience (i.e., a value of variable experience below the median) and those resulted more experienced (i.e., with a value of experience above or equal to the median) and compare, in columns 8 and 9, the average auction house outcomes and characteristics of the two subsamples. In line with our hypothesis, we find that the more experienced auction houses have a 5 percent higher sale rate compared to low experience ones, and they predict more accurately the hammer prices.

We also find that there is little variability in the relative size of the estimation range (multiple). The mean and median coincide at 1.3 and the standard deviation is 0.2. These findings imply that the high estimate is 30 percent higher than the low estimate, on average, and contrast with the view that auction houses mechanically inflate the estimation ranges to increase the probability of hammered prices falling within the range.

\section{Insert Table 3 approximately here}

Our univariate results in Table 3 are consistent with the hypothesis that more experienced auction houses are more likely to sell and better able to predict prices than less experienced ones. In the next sections we present more formal analyses and robustness checks to explore whether this relationship survives after controlling for omitted variables and other endogeneity concerns.

\subsection{Baseline empirical results}

Table 4 contains the results of the ordinary least squares (OLS) estimations of Equation (1) for our two dependent variables: sold (Panel A) and distance (Panel B). ${ }^{11}$ In

\footnotetext{
${ }^{11}$ We present the linear probability model coefficients obtained through OLS estimations of Equation (1) on the binary variable sold because these estimations do not rely on any distributional assumption for the error term and provide a simple interpretation of marginal effects (Angrist and Pischke, 2008). However, the average marginal effects estimated with a non-linear probit model, not reported here, yield qualitatively identical results to those reported.
} 
each panel, columns 1 to 6 report the coefficients estimated using specifications $I$ to $V I$, respectively, as described in Section 3.4.

Results in Panel A of Table 4 show that experience has a positive effect on the probability of a painting being sold. The positive coefficients are statistically significant in columns 1 to 5. Economically, the coefficients in columns 1 to 3 (the lowest coefficients that are statistically significant) are roughly equivalent and imply that a one standard deviation increase in experience in dealing with an artist increases the probability of selling that artist's works by around one percentage point. The coefficients in columns 4 and 5 suggest that a one standard deviation in experience increases the probability of selling that artist's works by 2.1 to 2.7 percentage points. These magnitudes are comparable to the economic significance of multiple, which is the coefficient that has, on average, the largest economic significance throughout the specifications. In fact, the coefficient for multiple implies that increasing the ratio of the high estimate to the low estimate by one standard deviation (that is, widening the estimation range) increases the probability of sale on average by 1.9 to 2.4 percentage points.

Our results also show that the coefficient for variable experience in column 6 of Panel A is neither economically nor statistically significant. Recall that in this specification, we have added the interaction of auction house, town, and artist fixed effects. Therefore, this specification exploits the time variation of auctions carried out in the same salesroom for the same artist, and analyzes whether changes in the level of experience yield a higher sales probability. Ideally, this specification should control for a potentially endogenous matching of certain artists to particular salesrooms in a given town. In practice, the changes in variable experience within a given artist, town, and house combination are very small, and they are not likely to capture a true accumulation of experience for a given house. For example, changes in experience could capture crosssectional changes in the proportion of the artist's works auctioned in this house and town. This is because by construction, this variable compares the number of auctions for a given artist in a given house-town combination to the number of auctions of that same artist across all houses, and this comparison is essentially cross-sectional. Moreover, the value of experience could decrease (increase) discretely in time for a given auction house 
and artist whenever past auctions exit (enter) the numerator because they occurred earlier than (within) the five-year time horizon considered.

To see why the within-artist, house, and town variation does not necessarily measure increases or decreases of experience for a given artist in a given house-town combination, Table A.1 in the Appendix shows the auctions carried out for one of the artists that is most present in our sample (Lucio Fontana) in some of the houses where paintings by this artist have been auctioned. From the table, it should be clear that the within house, town, and artist variation is very low. For example, experience levels for Christie's London are quite stable at around 0.28, in Sotheby’s Milan at around 0.15, and so on. The low variation in experience makes it likely that this model specification yields results with low statistical power, as the one observed in column 6.

More importantly, the larger changes in experience within a given house for a given artist could be associated either to cross-sectional changes in the composition of the paintings auctioned through the different auction houses, or to discrete changes in the numerator of variable experience due to the time horizon considered to construct this variable, rather to experience accumulation or decumulation. As an example, observe the decrease in experience for Sotheby's London in the February 2008 auctions, from 0.26 to 0.23. It is unlikely that this is due to a loss in experience in Fontana by this auction house. Rather, this change most likely reflects the fact that in June and October 2007, Christie's London featured an exceptional number of paintings of Fontana (23), thus lowering the levels of relative experience for the other houses. By the same token, the change in experience in Sotheby's London in the October 2006 auctions, from 0.33 to 0.29, is not likely to correspond to a loss of experience of this house with this artist. Most likely, this change is due to the fact that the auctions of 11 paintings of Fontana which took place in June 2001 are not considered anymore in the numerator of variable experience. While the changes in relative experience due to compositional changes in the cross-section of auction houses can be accounted for by using an absolute measure of experience (see the next section), the variation in experience due to the time horizon considered cannot. For these reasons, we decide to drop specification $V I$ in the robustness analyses that we will present in Tables 5, 6, and 7. 
In Panel B of Table 4 we estimate the effect of experience on the accuracy of the pre-auction price estimates for the sample of sold paintings. We measure prediction accuracy with variable distance, i.e., the absolute value of the difference between the midpoint of the estimation range and the hammer price, divided by the hammer price. Consistent with our main hypothesis, the coefficient for variable experience is negative in all specifications except the last, and it is statistically significant in the specifications of columns 1 to 4 . In terms of economic significance, the coefficients for experience in columns 1 to 4 of Panel B are similar and imply that a one standard deviation increase in experience leads to a reduction in the distance from the actual hammer price to the midpoint of the estimation range of around 1.8 percentage points, equivalent to a seven percent reduction relative to the average distance.

In Panel B, coefficients for experience are not significant in columns 5 and 6. The coefficient in column 6 is possibly not statistically significant because of the low variation of experience within the different groups formed by the combinations of auction houses, towns, and artists, as discussed above. On the other hand, the loss of significance for this coefficient in column 5 could be due to the smaller sample size; in fact, by forcing comparisons to be done for the same artist, town, and year, we lose almost 40 percent of the observations relative to those in column 1. An alternative interpretation for the lack of significance in column 5, in the light of the results of column 5 in Panel A, is that, conditional on a sale, auction houses do not use their experience to differentiate themselves from their direct competitors by providing more accurate price predictions. Still, auction houses use their experience to maximize the probability of a sale, as shown by the large coefficient for experience in column 5 of Panel A. ${ }^{12}$ This finding is consistent with anecdotal evidence, obtained through conversations with different auctioneers, that auction houses direct their main efforts to obtain a sale, leaving the accuracy of the predictions as a second-order concern. This interpretation makes sense,

\footnotetext{
${ }^{12}$ Notice that estimations in Panel B are performed on the sample of sold paintings. Given that experienced houses are more likely to sell a painting (Panel A), this suggests that the accuracy of experienced houses must be larger than the one of non-experienced houses in the complete sample of sold and unsold paintings. In fact, in untabulated results we broaden the definition of prediction accuracy to the complete sample by defining a dummy taking a one whenever the painting was sold or when the hammered price lied within the estimation range, and zero otherwise. Results show that experience has a positive and statistically significant impact on prediction accuracy defined in this way.
} 
because the auctioneers are rewarded directly through the buyer's premium when achieving a sale, but they do not receive a direct compensation for better pre-sale estimations.

\section{Insert Table 4 approximately here}

Before we turn to extensions for our baseline analysis, we briefly discuss the signs and significance of the control variables. First of all, we find that the effect on the sale probability of an artist's presence in previous auctions (measured by variable artist visibility) is concave in the specifications without artist fixed effects, and negative when artist fixed effects are included. Overall, these results suggest that rarity is still valuable, since artists that appear too frequently in auctions seem to be neglected by art buyers. Alternatively, this negative effect of the artist's visibility could be explained through an "anchoring" effect if sellers set higher reserve prices when there is a record of previous prices of paintings by the same author, and reserve prices are based on the highest sale prices recorded at auction or on marked-up price averages.

From the coefficient of first auction, we find that, in the cross-section of artists (models 1 and 2), paintings that have been put up for auction for the first time in a long period seem to be more appreciated by art buyers. In fact, the probability of sale for items auctioned for the first time since 1990 is larger than the probability of sale for works auctioned more recently. This finding is in line with the result of artist visibility and suggests a "freshness effect" that increases buyers' interest in paintings that are relatively new to the market. ${ }^{13}$ Again, this result might alternatively be explained by an anchoring argument: if the painting was traded (or auctioned) in the past, a reference price (or, in the case of a bought in, some valuable information) would be available to the seller, who might be induced to change her reserve price to reflect the information obtained at the first auction. ${ }^{14}$ Notice that with artist fixed effects, the coefficient becomes negative,

\footnotetext{
${ }^{13}$ There is anecdotal evidence that buyers may prefer works of art that have not been for sale for many years to those that have been on the market recently. See, for example, the interview with Christie's deputy chairperson in "How to buy art at auction, by Christie's Orlando Rock," The Telegraph, October 24, 2012.

${ }^{14}$ This argument would be even stronger if the seller is the buyer of the painting in the previous auction, as her return would be positive only if the hammer price is adequately higher (to compensate also the brokerage fee) than the purchase hammer price.
} 
suggesting that it is harder to sell a given painting of a given artist the first time it goes in auction.

In contrast, the sign of the coefficients for artist visibility and first auction in Panel $\mathrm{B}$ are negative and positive, respectively, suggesting that auction houses can provide more accurate estimations for the value of paintings of more visible artists, or of previously auctioned artworks. This is consistent with the idea that the availability of information about past auctions generates additional public information that can be used to improve auction houses’ estimations (Abowd and Ashenfelter, 1988; Bauwens and Ginsburgh, 2000; Sproule and Valsan, 2006).

Our results also document that the market share positively affects the probability of a sale, but it decreases the precision of the pre-auction estimates. The market share is expected to be correlated with a larger probability of a sale, as it is defined in terms of total sales. On the other hand, the fact that market share is negatively related with the precision of the estimates could be explained if investors are more credulous about the estimates given by the large auction houses (Mei and Moses, 2005).

Finally, we find that wider estimates ranges (i.e., higher values of variable multiple) are associated with higher probabilities of sale. This result is surprising if we interpret the width of the range as a measure of the uncertainty about the value of the piece of art (Ashenfelter and Graddy, 2006; McAndrew et al., 2012). However, the meaning of the range of the estimation width is controversial in the literature on art auctions, and our findings are in line with Ekelund et al. (1998) and Ashenfelter et al. (2003), who propose a different interpretation for this variable. They point out that, rather than measuring the uncertainty of the value of the artwork, the size of the range indicates the level of the reserve price relative to the auction house's prediction. In their view, a narrow range indicates that the seller sets a relatively high reserve price, thus pushing the low estimate upward towards the high estimate. If this is the case, a small range reduces the probability of sale of a given piece of art, because the reserve price is too high. ${ }^{15}$ Consistently with

\footnotetext{
${ }^{15}$ We held some informal conversations with art dealers who confirmed this view. For auction houses, the most important input in the estimation range seems to be the low estimate, which is adjusted according to the valuation provided by experts and by the seller's reserve price. The high estimate is often set as an approximate multiple of this value. Consistently with this view, our data show that there is not much variability in the width of the estimation range, since in most cases the high estimate is set at 1.3 times the low estimate.
} 
this view, Ekelund et al. (1998) show that the range is negatively and significantly related to the likelihood of no sale and Ashenfelter et al. (2003) find that wider estimate ranges are associated with a higher probability of sale.

On the other hand, we find that the distance from the midpoint of the estimation range to the actual hammer price is larger when auction houses set wider estimation ranges. This is consistent with larger estimation intervals revealing greater uncertainty about an artwork's value. An alternative explanation, which associates wider estimation ranges with lower reserve prices, is also consistent with the result: A reduced reserve price could trigger a sale at lower prices and, consequently, further away from the midpoint of the estimation range.

\subsection{Extensions}

The results in Table 4 could raise the concern that variable experience is capturing other phenomena which are unrelated to the accumulation of information. In this section, we extend our analysis to present additional evidence that our results are driven by experience and not by other confounding stories.

The first concern is that our results in Table 4 are driven by changes in the composition of the market share or the market power auction houses for a given artist. As explained above, variable experience could change over time due to changes in the denominator, i.e., due to the presence of this artist's paintings in other houses. To mitigate this concern, we substitute our relative measure of experience with absolute experience, defined as the number of paintings of the artist that have been auctioned in the auction house and town during the previous 5 years. Results using this measure are contained in Table 5. As discussed above, we only present the estimations for the first five model specifications described in Section 3.4. Findings in this case are very similar to those in Table 4 in terms of both economic and statistical significance. Confirming our previous evidence, we still find a significant effect of experience, especially on the probability of a sale.

\section{Insert Table 5 approximately here}


Another concern in the previous estimations is that the results are driven by Sotheby's and Christie's, the two major players in the art market. This concern is plausible if investors are credulous, i.e., they are led to believe that the paintings auctioned by major houses are more valuable, or that estimates by these houses are more accurate predictors of their true value (Mei and Moses, 2005). The inclusion of auction house and town fixed effects accounts for this potential endogeneity issue, especially in the estimation in column 2 of Table 4, where estimations are done within a given auction house and town. However, the concern remains to the extent that most of the observations in the sample occur in either of these two houses. In our sample, almost half of the observations (49 percent) correspond to auctions taking place in either Christie's or Sotheby's. Therefore, to mitigate the concern that the results are driven by these top players, we re-run the estimations in Table 4 excluding Christie's and Sotheby's. The results, contained in Table 6, are very similar to our baseline results. Throughout the different specifications, we find that experience significantly increases the likelihood of a sale and decreases the distance to the midpoint of the estimation range. Furthermore, these results are still statistically significant in spite of the sample size reduction (and the resulting reduction in the variance of the experience variable), except in the specification in columns 9 and 10, which correspond to the most restrictive models with lower power (i.e., specification $V$ ).

\section{Insert Table 6 approximately here}

Next, we would like to present some further evidence that is consistent with our findings being driven by the accumulation of information, as measured by experience. For this purpose, we estimate the different variants of Equation (1) on a market where information asymmetry is likely to be particularly severe, i.e. where there is not much prior public information, and hence a deeper understanding of the tastes and trends for different artists is required. As argued by Velthuis (2011b), the Contemporary market is the most volatile and uncertain segment of the art market. This fact can be confirmed by observing that modern and contemporary art is the collecting category that has registered the highest growth rate and which has reached the largest record prices in recent years 
(some well beyond the estimation range). ${ }^{16}$ Italian contemporary art has also followed a similar pattern as the Italian art sales held in London at major auction houses have recently fetched record breaking prices. ${ }^{17}$ The estimation process of contemporary artworks is therefore more complex: These pieces of art are more likely to fall in and out of fashion and hence tend to show higher price volatility over time than artworks with a longer history (Pownall, 2013).

Precisely because of the higher uncertainty associated with contemporary art, we expect that experience matters more in explaining differences between auction house outcomes (the sale rates and the truthfulness of estimates) when contemporary art paintings are put up at auctions. Moreover, experienced brokers should have higher incentives to present truthful pre-sales estimates (rather than, say, inflate the prices to obtain higher commissions). This is because their reputation is at stake, and they are interested in maintaining their client relationships and expand their network, which is the foundation of their experience. ${ }^{18}$

Table 7 reports the results of estimating the different variants of Equation (1) on the subsample of contemporary art. Overall, the results confirm our previous findings on the impact of auction houses' experience on auction outcomes. In this case results are statistically significant in all of the tested specifications - in spite of the reduction in the sample size -, and the economic significance of the coefficients for the probability of a sale is larger than the baseline specification. These results are consistent with our hypothesis that accumulation of information matters in a framework with severe information asymmetry.

\section{Insert Table 7 approximately here}

\footnotetext{
${ }^{16}$ Over the last 40 years, the standard deviation of the Mei and Moses post war and contemporary index has significantly overcome the standard deviation of both the impressionist-modern and old master art indexes (Deloitte-ArtTactic, 2014).

${ }^{17}$ See, for example, the results of the October 2015 auctions for Post-War and Contemporary Art and Italian Sale at Christie's in the following link: http://www.christies.com/auctions/2015/post-war-andcontemporary-art-london-october-2015.

${ }^{18}$ Investment banks face a similar dynamic trade-off. Setting strict standards in evaluating firms is costly in the short run but beneficial in the long run, since it reduces the probability of market lemons and damage to their reputation (Chemmanur and Fulghieri, 1994).
} 
Our final robustness test explores whether our choice of length of the period over which we calculate the experience variables matters for our results. For this purpose, we replicate our baseline estimations measuring our experience variables over different time horizons $T$, from 1 to 10 years. Figures 1.A and 1.B contain a graphic representation of the estimated coefficients and their 95\% confidence intervals for the regressions explaining the likelihood of a sale and the absolute distance to the midpoint of the estimation range, respectively. The horizontal axis contains the number of years over which we construct the experience variable, i.e., the time horizon, and the vertical axis contains the magnitude of the coefficient. For the sake of brevity, the figures report the estimated coefficients for relative experience with the specification containing artist fixed effects (i.e., those corresponding to specification III of our identification strategy). The results show that the point estimates of the regressions of experience on the likelihood of a sale are positive for all the time horizons and statistically significant at a 95\% level for horizons greater than 3 years. Similarly, the coefficients of experience on the distance to the midpoint of the estimation range are negative for all time horizons, and also statistically significant for $T$ greater than 3 years. Unreported results using other sets of fixed effects exhibit the same qualitative characteristics as the ones reported. These results confirm that the findings are not driven by the choice of the time horizon over which experience is measured.

An interesting feature of Figures 1.A and 1.B is that the point estimates for the likelihood of sale are increasing and the point estimates for the absolute distance are decreasing on the time horizon. This result, which also appears in other unreported analyses using absolute experience and/or different sets of fixed effects, suggests that experience is somehow accumulated over time. That is, an auction that occurred, say, five to eight years ago still contains information that the auction house can use to enhance the probability of sale or the price estimates. However, these increases or decreases of the effect of experience on auction outcomes over different time horizons seem to occur at a decreasing rate, especially when the dependent variable is the likelihood of a sale. In other words, an auction occurring in the recent past (say, within the previous one to three years) seems to provide more information than an auction occurring in the more remote past (say, eight to ten years ago). Nevertheless, we would like to stress that these results 
are only suggestive, as we cannot statistically distinguish the coefficients across different time horizons.

\section{Insert Figure 1 approximately here}

\section{Conclusions}

In the art market setting, this article investigates whether and the extent to which more informed brokers affect market outcomes. Using a unique data set of auctions of Italian paintings, we capture the availability of privileged private information about sellers' and bidders' behavior at auction with an experience variable that accounts for the number of times an art broker (i.e. the auction house) has auctioned the artworks of a certain artist in a given location.

Such variable accounts for the auction house's proximity with the sellers and the potential buyers of a specific type of assets and proxies for auction house's ability to extract private information from both the market participants. We observe auction outcomes in terms of probability of success (sale) at auction and precision of pre-sale estimates.

We find evidence that auctions performed by experienced brokers are more likely to lead to a sale, thus increasing the asset liquidity. We also find some evidence that presale estimates provided by experienced auction houses are more precise than those provided by less informed competitors. This finding suggests that auction houses improve the quality of information available to market participants. However, results for the precision of the estimates are not statistically significant in specifications that control for demand-side effects for a given artist, suggesting that providing precise estimates is a second-order concern for art market brokers, who rather focus on maximizing the probability of a sale. Our results do not seem to be driven by investors' credulousness, and are larger (in economic terms) for markets where information asymmetry is a greater concern, suggesting that the effects we find in the data are due to accumulation of information by experienced brokers. 
Our findings show that the broker's experience is beneficial to both the demandand (especially) supply-side market participants. The former benefit from experienced auctioneers in terms of obtaining more precise and reliable estimates; the latter benefit in terms of a higher probability of sale. 


\section{References}

Abowd, J. and Ashenfelter, O. (1988), Art Auctions: Prices Indices and Sale Rates for Impressionist and Contemporary Pictures, mimeo, Department of Economics, Princeton University.

Agarwal, S. and Hauswald, R. (2010), Distance and Private Information in Lending, Review of Financial Studies, 23(7): 2757-2788.

Angrist, J. D. and Pischke, J. S. (2008), Mostly Harmless Econometrics: An Empiricist's Companion, Princeton University Press, Princeton, NJ.

Ashenfelter, O. (1989), How Auctions Work for Wine and Art, Journal of Economic Perspectives, 3(3): 23-36.

Ashenfelter, O. and Graddy, K. (2003), Auctions and the Price of Art, Journal of Economic Literature, 41(3): 763-788.

Ashenfelter, O. and Graddy, K. (2006), Art Auctions, in Ginsburgh, V. and Throsby, D. (eds.), Handbook of the Economics of Arts and Culture, Elsevier, North Holland, Amsterdam: 909-945.

Ashenfelter, O., Graddy, K., and Stevens, M. (2003), A Study of Sale Rates and Prices in Impressionist and Contemporary Art Auctions, mimeo, Economics Department, University of Oxford.

Baumol, W. J. (1986), Unnatural Value: Or Art Investment as Floating Crap Game, American Economic Review, Papers and Proceedings, 76(2): 10-14.

Bauwens, L. and Ginsburgh, V. (2000), Art Experts and Auctions: Are Pre-sale Estimates Unbiased and Fully Informative? Recherches Économiques de Louvain/Louvain Economic Review, 66(2): 131-144.

Beggs, A. and Graddy, K. (2009), Anchoring Effects: Evidence from Art Auctions, American Economic Review, 99(3): 1027-1039.

Benveniste, L. M., Busaba, W. Y., and Wilhelm, W. J. (2002), Information Externalities and the Role of Underwriters in Primary Equity Markets, Journal of Financial Intermediation, 11(1): 61-86.

Benveniste, L. M. and Spindt, P. A. (1989), How Investment Bankers Determine the Offer Price and Allocation of New Issues, Journal of Financial Economics, 24(2): 343-361.

Berger, A. N. and Udell, G. (1995), Relationship Lending and Lines of Credit in Small Firm Finance, The Journal of Business, 68(3): 351-381.

Bhattacharya, S. and Thakor, A. V. (1993), Contemporary Banking Theory, Journal of Financial Intermediation, 3(1): 2-50.

Biglaiser, G. (1993), Middlemen as Experts, RAND Journal of Economics, 24(2): 212-223.

Bonus, H. and Ronte, D. (1997), Credibility and Economic Value in the Visual Arts, Journal of Cultural Economics, 21(2): 103-118.

Chang, X., Shekhar, C., Tam, L. H. K., and Yao, J. (2015), Industry Expertise, Information Leakage, and the Choice of M\&A Advisors, Journal of Business Finance \& Accounting, forthcoming.

Chemmanur, T. J. and Fulghieri, P. (1994), Investment Bank Reputation, Information Production, and Financial Intermediation, Journal of Finance, 49(1): 57-79.

Deloitte-ArtTactic (2014), Art \& Finance Report 2014.

Ekelund, R., Ressler, R. and Watson, J. (1998), Estimates, Bias and "No Sales" in LatinAmerican Art Auctions, 1977-1996, Journal of Cultural Economics, 22(1): 33-42.

Goetzmann, W. N. (1993), Accounting for Taste: Art and the Financial Markets over Three Centuries, The American Economic Review, 83(5): 1370-1376.

Gompers, P., Kovner, A., Lerner, J., and Scharfstein, D. (2008), Venture capital investment cycles: The impact of public markets, Journal of Financial Economics, 87(1): 1-23. 
Hauswald, R. and Marquez, R. (2006), Competition and Strategic Information Acquisition in Credit Markets, The Review of Financial Studies, 19(3): 967-1000.

Khwaja, A. I. and Mian, A. (2008), Tracing the Impact of Bank Liquidity Shocks, American Economic Review, 98(4): 1413-1442.

Lacetera, N., Bradley, J. L., Pope, D. and Sydnor, J. R. (2013), Bid Taker or Market Makers? The Effect of Auctioneers on Auction Outcomes, NBER Working Paper No. 19731, December.

McAndrew, C. (2010), Fine Art and High Finance, Bloomberg Press, New York.

McAndrew, C., Smith, J. and Thompson, R. (2012), The Impact of Reserve Prices on the Perceived Bias of Expert Appraisals of Fine Art, Journal of Applied Econometrics, 27(2): 235-252.

Mei, J. and Moses, M. (2005), Vested Interest and Biased Price Estimates: Evidence from an Auction Market, Journal of Finance, 60(5): 2409-2435.

Milgrom, R. and Weber, R. J. (1982), A Theory of Auctions and Competitive Bidding, Econometrica, 50(5): 1089-1122.

Millon, M. H. and Thakor, A. (1985), Moral Hazard and Information Sharing: A Model of Financial Information Gathering Agencies, Journal of Finance, 40(5): 1403-1422.

Ongena, S. and Smith, D. C. (2001), The Duration of Bank Relationships, Journal of Financial Economics, 61(3): 449-475.

Petersen, M. A. (2004). Information: Hard and Soft, mimeo, Northwestern University.

Petersen, M. A. and Rajan, R. G. (2002), Does Distance Still Matter? The Information Revolution in Small Business Lending, Journal of Finance, 57(6): 1540-6261.

Pownall, R. A. J. (2013), Art Market Indexes, Deloitte-ArtTactic, Art \& Finance Report 2013: 61-64.

Ramakrishnan, R. T. S. and Thakor, A. V. (1984), Information Reliability and a Theory of Financial Intermediation, Review of Economic Studies, 51(3): 415-432.

Spatt, C. and Srivastava, S. (1991), Preplay Communication, Participation Restrictions, and Efficiency in Initial Public Offerings, The Review of Financial Studies, 4(4): 709-726.

Sproule, R. and Valsan, C. (2006), Hedonic Model and Pre-auction Estimates: Abstract Art Revisited, Economics Bulletin, 26(5): 1-10.

Stein, J. C. (2002), Information Production and Capital Allocation: Decentralized versus Hierarchical firms, The Journal of Finance, 57(5): 1891-1921.

Uzzi, B. and Gillespie, J. J. (2002), Knowledge Spillover in Corporate Financing Networks: Embeddedness, Network Transitivity, and Trade Credit Performance, Strategic Management Journal, 23(7): 595-618.

Velthuis, O. (2011a), Art Markets, in Towse, E. (ed.), A Handbook of Cultural Economics, $2^{\text {nd }}$ Edition, Edward Elgar, Cheltenham: 33-42.

Velthuis, O. (2011b), Art Dealers, in Towse, E. (ed.), A Handbook of Cultural Economics, $2^{\text {nd }}$ Edition, Edward Elgar, Cheltenham: 28-32.

Velthuis, O. (2013), Globalization and Commercialization of the Art Market, in Dumbadze, A. and Hudson, S. (eds.), Contemporary Art: 1989 to the Present, Wiley-Blackwell, Chichester: 369-378.

Vincent, D. R. (1995), Bidding Off the Wall: Why Reserve Prices May Be Kept Secret, Journal of Economic Theory, 65(2): 575-584. 
Table 1. Sample distribution.

This table contains the distribution of the sample of the Italian paintings auctioned between years 2000 and 2008 according to: year of auction (Panel A), art category (Panel B), auction house (Panel C), city where the auction was held (Panel D), country where the auction was held (Panel E), and auction house by collecting category (Panel F).

Panel A. Distribution by year

\begin{tabular}{|c|c|c|c|c|}
\hline Year & Num. obs & $\%$ total & Num. sold & \% sold \\
\hline 2000 & 4,532 & 9.1 & 2,734 & 60.3 \\
\hline 2001 & 4,594 & 9.3 & 2,600 & 56.6 \\
\hline 2002 & 4,622 & 9.3 & 2,722 & 58.9 \\
\hline 2003 & 4,564 & 9.2 & 2,681 & 58.7 \\
\hline 2004 & 5,110 & 10.3 & 3,117 & 61.0 \\
\hline 2005 & 5,600 & 11.3 & 3,420 & 61.1 \\
\hline 2006 & 7,296 & 14.7 & 4,449 & 61.0 \\
\hline 2007 & 8,342 & 16.8 & 4,841 & 58.0 \\
\hline 2008 & 4,913 & 9.9 & 2,475 & 50.4 \\
\hline Total & 49,573 & 100 & 29,039 & 58.6 \\
\hline
\end{tabular}

Panel B. Distribution by art category

\begin{tabular}{lcccc}
\hline Category & Num. obs & \% total & Num. sold & \% sold \\
\hline Old Masters & 24,090 & 48.6 & 13,021 & 54.1 \\
XIX Cent. & 9,142 & 18.4 & 5,059 & 55.3 \\
XX Cent. & 16,341 & 33.0 & 10,959 & 67.1 \\
Total & 49,573 & 100.0 & 29,039 & 58.6 \\
\hline
\end{tabular}

Panel C. Distribution by auction house

\begin{tabular}{lcccc}
\multicolumn{5}{l}{ Panel C. Distribution by auction house } \\
\hline Auction house & Num. obs & \% total & Num. sold & \% sold \\
\hline Finarte-Semenzato & 12,648 & 25.5 & 6,035 & 47.7 \\
Sotheby's & 12,524 & 25.3 & 8,184 & 65.3 \\
Christie's & 11,526 & 23.3 & 7,826 & 67.9 \\
Other auction houses* & 12,875 & 26.0 & 6,994 & 54.3 \\
Total & 49,573 & 100 & 29,039 & 58.6 \\
\hline
\end{tabular}

\section{Panel D. Distribution by city}

\begin{tabular}{|c|c|c|c|c|}
\hline City & Num. obs & $\%$ total & Num. sold & \% sold \\
\hline Milan & 17,725 & 35.8 & 9,914 & 55.9 \\
\hline London & 11,184 & 22.6 & 7,278 & 65.1 \\
\hline Rome & 5,303 & 10.7 & 2,947 & 55.6 \\
\hline New York & 3,692 & 7.4 & 2,547 & 69.0 \\
\hline Other non-Italian cities** & 6,085 & 12.3 & 3,543 & 58.2 \\
\hline Other Italian cities $* * *$ & 5,584 & 11.3 & 2,810 & 50.3 \\
\hline Total & 49,573 & 100 & 29,039 & 58.6 \\
\hline
\end{tabular}

* See Panel F.

** Amsterdam, Berlin, Cologne, Copenhagen, Easton Neston, Geneva, Hannover, Helsinki, Los Angeles, Melbourne, Montecarlo, Munich, Paris, San Francisco, Stockholm, Sydney, Vienna and Zurich.

*** Bologne, Florence, Goito (Mantua), Naples, Prato, Turin, and Venice.

**** Australia, Denmark, Finland, Germany, Holland, Montecarlo, Sweden, and Switzerland.

\begin{tabular}{lcccc}
\multicolumn{4}{l}{ Panel E. Distribution by country } \\
\hline Country & Num. obs & \% total & Num. sold & \% sold \\
\hline Italy & 28,612 & 57.7 & 15,671 & 54.8 \\
UK & 11,186 & 22.6 & 7,280 & 65.1 \\
USA & 3,884 & 7.8 & 2,699 & 69.5 \\
Austria & 2,714 & 5.5 & 1,306 & 48.1 \\
France & 1,355 & 2.7 & 901 & 66.5 \\
Other countries**** & 1,822 & 3.7 & 1,182 & 64.9 \\
Total & 49,573 & 100 & 29,039 & 58.6 \\
\hline
\end{tabular}

Panel F. Distribution by auction house and collecting category

\begin{tabular}{lcccr}
\hline Auction house & \% Old $\mathbf{~}$. & \% $^{\text {th }}$ Cent. & \% $\mathbf{2 0}^{\text {th }}$ Cent. & \multicolumn{1}{c}{ Num. } \\
\hline ARTCURIAL BRIEST & 15.9 & 5.8 & 78.3 & 346 \\
BONHAMS \& BUTTERFIELDS & 73.5 & 21.5 & 5.0 & 1,681 \\
BRUUN RASMUSSEN & 66.0 & 26.4 & 7.6 & 53 \\
BUKOWSKIS & 84.2 & 5.6 & 10.3 & 234 \\
CAMELS COHEN & 0.0 & 0.0 & 100.0 & 9 \\
CHRISTIE'S & 48.6 & 21.5 & 29.9 & 11,526 \\
DOROTHEUM & 87.1 & 9.6 & 3.4 & 2,714 \\
DOYLE & 74.1 & 14.6 & 11.3 & 301 \\
FARSETTI ARTE & 11.9 & 11.7 & 76.4 & 1,225 \\
FINARTE-SEMENZATO & 26.4 & 19.9 & 53.8 & 12,648 \\
GLERUM ACTIONEERS & 50.0 & 25.0 & 25.0 & 4 \\
GRISEBACH & 0.0 & 0.0 & 100.0 & 17 \\
KOLLER & 72.8 & 14.5 & 12.7 & 338 \\
LEMPERTZ & 73.0 & 6.5 & 20.6 & 418 \\
NEUMEISTER & 65.9 & 23.6 & 10.6 & 246 \\
PANDOLFINI & 46.1 & 17.8 & 36.0 & 1,587 \\
PHILLIPS & 67.1 & 12.9 & 20.0 & 325 \\
PIASA & 72.9 & 3.7 & 23.4 & 107 \\
PORRO \& C. & 47.9 & 23.1 & 29.0 & 1,905 \\
SAN MARCO & 61.3 & 8.3 & 30.4 & 710 \\
SOTHEBY'S & 58.1 & 18.2 & 23.7 & 12,524 \\
SWANN & 71.4 & 14.3 & 14.3 & 7 \\
TAJAN & 79.8 & 9.1 & 11.1 & 648 \\
Total & 48.6 & 18.4 & 33.0 & 49,573 \\
\hline
\end{tabular}




\section{Table 2. Cross-sectional distribution of average experience across auction houses (selected artists).}

This table shows the average value of variable Experience in each auction house and town, for nine different artists in the sample: Canaletto, Luca Giordano, and Tiziano (belonging to the Old Masters collecting category); Beppe Ciardi, Vincenzo Irolli, and Attilio Pratella (belonging to the $19^{\text {th }}$ Century collecting category); and Tano Festa, Lucio Fontana, and Mario Sironi (belonging to the $20^{\text {th }}$ Century
collecting category). Variable Experience is defined as the ratio of the number of times the auctioneer in a given town has auctioned works by the artist in the previous five years, to the number of times that works of the same artist have been auctioned in any auction house over the same period. Average values for each artist and auction house combination are calculated over the 2000-2008 period.

\begin{tabular}{|c|c|c|c|c|c|c|c|c|c|}
\hline & \multicolumn{3}{|c|}{ Old Masters } & \multicolumn{3}{|c|}{$19^{\text {th }}$ Century } & \multicolumn{3}{|c|}{$20^{\text {th }}$ Century } \\
\hline & CANALETTO & $\begin{array}{c}\text { LUCA } \\
\text { GIORDANO }\end{array}$ & TIZIANO & $\begin{array}{l}\text { BEPPE } \\
\text { CIARDI } \\
\end{array}$ & $\begin{array}{c}\text { VINCENZO } \\
\text { IROLLI } \\
\end{array}$ & $\begin{array}{c}\text { ATTILIO } \\
\text { PRATELLAA } \\
\end{array}$ & $\begin{array}{l}\text { TANO } \\
\text { FESTA } \\
\end{array}$ & $\begin{array}{c}\text { LUCIO } \\
\text { FONTANA } \\
\end{array}$ & $\begin{array}{l}\text { MARIO } \\
\text { SIRON }\end{array}$ \\
\hline ARTCURIAL BRIEST MONTECARLO & . & & . & . & & 0.000 & & & 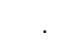 \\
\hline ARTCURIAL BRIEST PARIS & & & & . & & & 0.002 & 0.004 & 0.005 \\
\hline BONHAMS \& BUTTERFIELDS LONDON & 0.028 & 0.039 & 0.044 & & 0.014 & 0.006 & . & & . \\
\hline BONHAMS \& BUTTERFIELDS NEW YORK & 0.010 & & . & . & 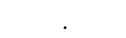 & & . & . & . \\
\hline BONHAMS \& BUTTERFIELDS SAN FRANCISCO & 0.014 & 0.000 & & . & & 0.000 & & . & . \\
\hline BRUUN RASMUSSEN COPENHAGEN & . & & 0.007 & . & . & & . & . & . \\
\hline BUKOWSKIS HELSINKI & & 0.000 & & & & . & & & . \\
\hline BUKOWSKIS STOCKHOLM & 0.004 & 0.011 & 0.026 & & & . & . & 0.008 & . \\
\hline CHRISTIE'S AMSTERDAM & 0.000 & 0.000 & 0.006 & 0.000 & 0.000 & 0.000 & & & . \\
\hline CHRISTIE'S LONDON & 0.328 & 0.168 & 0.348 & 0.015 & 0.069 & 0.043 & 0.000 & 0.279 & 0.015 \\
\hline CHRISTIE'S MILAN & 0.000 & 0.004 & . & . & & & 0.141 & 0.047 & 0.166 \\
\hline CHRISTIE'S NEW YORK & 0.132 & 0.084 & 0.012 & 0.016 & 0.090 & 0.041 & & 0.022 & . \\
\hline CHRISTIE'S PARIS & & 0.000 & 0.010 & & & & & 0.005 & . \\
\hline CHRISTIE'S ROME & 0.009 & 0.067 & 0.011 & 0.248 & 0.240 & 0.295 & 0.000 & 0.000 & 0.000 \\
\hline CHRISTIE'S SYDNEY & & & & & & & & 0.000 & 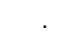 \\
\hline DOROTHEUM VIENNA & 0.062 & 0.040 & 0.132 & . & 0.000 & 0.000 & 0.000 & 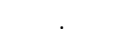 & 0.000 \\
\hline DOYLE NEW YORK & 0.010 & 0.004 & 0.009 & & 0.000 & . & & & \\
\hline FARSETTI ARTE PRATO & . & & . & 0.000 & 0.007 & & 0.039 & 0.017 & 0.035 \\
\hline FINARTE-SEMENZATO FLORENCE & . & & & & 0.000 & . & & & . \\
\hline FINARTE-SEMENZATO GOITO (MANTUA) & . & 0.000 & 0.000 & . & & . & & & . \\
\hline FINARTE-SEMENZATO MILAN & 0.000 & 0.080 & . & 0.355 & 0.171 & 0.184 & 0.411 & 0.063 & 0.324 \\
\hline FINARTE-SEMENZATO NAPLES & . & 0.000 & . & & 0.000 & i. & & & ${ }^{\circ}$ \\
\hline FINARTE-SEMENZATO ROME & . & 0.034 & . & 0.049 & 0.022 & 0.044 & 0.239 & 0.004 & 0.042 \\
\hline FINARTE-SEMENZATO VENICE & 0.009 & 0.015 & . & 0.028 & 0.018 & 0.000 & 0.064 & 0.000 & 0.015 \\
\hline GRISEBACH BERLIN & . & & . & . & & & & 0.000 & . \\
\hline KOLLER ZURICH & & 0.006 & 0.000 & . & . & 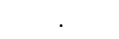 & . & 0.000 & 0.012 \\
\hline LEMPERTZ COLOGNE & 0.030 & 0.010 & 0.015 & . & . & 0.000 & & 0.008 & 0.000 \\
\hline NEUMEISTER MUNICH & . & 0.000 & 0.000 & 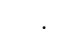 & & & & 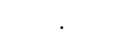 & . \\
\hline PANDOLFINI FLORENCE & 0.000 & 0.012 & 0.000 & 0.016 & 0.007 & 0.030 & 0.000 & & 0.000 \\
\hline PANDOLFINI MILAN & . & & 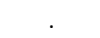 & . & & & 0.005 & . & . \\
\hline PHILLIPS LONDON & 0.046 & & 0.000 & . & 0.000 & . & & 0.000 & 0.092 \\
\hline PHILLIPS NEW YORK & 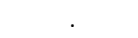 & & . & . & 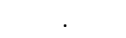 & & . & 0.010 & . \\
\hline PIASA PARIS & 0.000 & 0.008 & . & 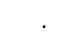 & & . & & & . \\
\hline PORRO \& C. MILAN & 0.000 & 0.017 & . & 0.040 & 0.019 & 0.021 & 0.033 & 0.008 & 0.028 \\
\hline PORRO \& C. TURIN & . & 0.000 & . & & & & & . & . \\
\hline SAN MARCO VENICE & . & 0.004 & 0.005 & 0.011 & 0.000 & . & 0.017 & . & 0.005 \\
\hline SOTHEBY'S AMSTERDAM & 0.004 & & 0.000 & 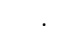 & & & & & . \\
\hline SOTHEBY'S LONDON & 0.184 & 0.199 & 0.187 & & 0.045 & 0.007 & 0.000 & 0.325 & 0.009 \\
\hline SOTHEBY'S MILAN & 0.011 & 0.069 & 0.020 & 0.124 & 0.177 & 0.178 & 0.087 & 0.152 & 0.241 \\
\hline SOTHEBY'S NEW YORK & 0.083 & 0.073 & 0.026 & 0.017 & 0.047 & 0.041 & & 0.013 & . \\
\hline TAJAN PARIS & 0.020 & 0.014 & & & 0.016 & 0.017 & & & . \\
\hline Average artist visibility & 121.2 & 121.8 & 80.7 & 49.5 & $\begin{array}{lll}77.7 \\
\end{array}$ & 73.2 & 153.5 & 234.6 & 100.1 \\
\hline
\end{tabular}


Table 3. Sample descriptive statistics.

This table contains descriptive statistics for Italian paintings auctioned between years 2000 and 2008. Reported are mean, median, and standard deviation values for the following variables: Experience is the ratio of the number of times the auctioneer in a given town has auctioned works by the artist in the previous five years, to the number of times that works of the same artist have been auctioned in any auction house during the past 5 years; Absolute experience is the number of times the auctioneer in a given town has auctioned works by the same artist in the previous five years; Sold is a dummy variable that equals one if the artwork is hammered, and zero if the artwork is unsold; Distance is the absolute value of the difference between the hammer price and the midpoint of the estimation range, divided by the hammer price; Artist visibility is the number of times works of the same artist have been auctioned in the previous five years, divided by 100; First auction is a dummy variable that equals one if the artwork has not been auctioned since 1990, zero otherwise; Market share is the ratio of the total sales in each house and town in a given year, divided by total sales for that year; Multiple is defined as the ratio between the maximum and the minimum values of the pre-sale price range. In columns 1-3 statistics are calculated for the whole sample. In columns 4 and 5 mean and standard deviation values are computed over the subsamples of paintings for which Experience is below the median. In columns 6 and 7 mean and standard deviation values are computed over the subsamples of paintings for which Experience is equal or above the median. Columns 8 and 9 report the $t$. statistic and the $p$-value for a $t$-test of equality of variable means across the subsamples.

\begin{tabular}{|c|c|c|c|c|c|c|c|c|c|}
\hline & $\begin{array}{c}(1) \\
\text { Mean }\end{array}$ & $\begin{array}{c}(2) \\
\text { Median }\end{array}$ & $\begin{array}{c}\text { (3) } \\
\text { St. Dev. }\end{array}$ & $\begin{array}{c}(4) \\
\text { Mean }\end{array}$ & $\begin{array}{c}\text { (5) } \\
\text { St. Dev }\end{array}$ & $\begin{array}{c}(6) \\
\text { Mean }\end{array}$ & $\begin{array}{c}(7) \\
\text { St. Dev }\end{array}$ & $\begin{array}{c}(8) \\
t \text {-stat }\end{array}$ & $\begin{array}{c}(9) \\
p \text {-value }\end{array}$ \\
\hline Experience & 0.168 & 0.105 & 0.205 & - & - & - & - & - & - \\
\hline Absolute experience & 6.620 & 2.000 & 11.249 & - & - & - & - & - & - \\
\hline Sold & 0.586 & 1.000 & 0.493 & 0.560 & 0.496 & 0.611 & 0.487 & -11.587 & 0.000 \\
\hline First auction & 0.930 & 1.000 & 0.254 & 0.951 & 0.217 & 0.910 & 0.286 & 17.688 & 0.000 \\
\hline Market share & 0.072 & 0.041 & 0.083 & 0.055 & 0.075 & 0.088 & 0.087 & -44.613 & 0.000 \\
\hline Multiple & 1.354 & 1.333 & 0.209 & 1.351 & 0.185 & 1.358 & 0.229 & -3.607 & 0.000 \\
\hline
\end{tabular}

* This variable is only defined for the subsample of sold paintings ( $N=29039$, out of which 13887 were auctioned in low experience auction houses and 15152 in high experience houses). 
This table reports the OLS coefficient estimates and robust standard errors (in brackets) of a test for the impact of auction houses' experience on auction otcomes. The dependent variables are: (i) Sold, i.e., a dummy variable that equals one if the artwork is hammered, and zero if the artwork is unsold (Panel A) and (ii) Distance, i.e., the absolute value of the difference between the hammer price and the midpoint of the estimation range, divided by the hammer price (Panel B). The explanatory variables are defined as follows: Experience is the ratio of the number of times the auctioneer in a given town has auctioned works by the artist in the previous five years, to the number of times that works of the same artist have been auctioned in any auction house during the past five years; Artist visibility is the number of times works of the same artist have been auctioned in the previous five years, divided by 100; First auction is a dummy variable that equals one if the artwork has not been auctioned since 1990, zero otherwise; Market share is the ratio of the total sales in each house and town in a given year, divided by total sales for that year; Multiple is the ratio between the maximum and the minimum values of the pre-sale price range. All estimations include an intercept (coefficient not reported). Coefficients are estimated over a sample of Italian paintings put in auction in years 2000-2008.

$* * *, * *$, and $*$ indicate statistical significance at the $1 \%, 5 \%$, and $10 \%$ levels, respectively.

Panel A. Dependent variable $=$ Sold

\begin{tabular}{lcccccc}
\hline & $(1)$ & $(2)$ & $(3)$ & $(4)$ & $(5)$ & $(6)$ \\
\hline Experience & $0.0533^{* * *}$ & $0.0520^{* * *}$ & $0.0508^{* * *}$ & $0.104^{* * *}$ & $0.130^{* * *}$ & 0.0168 \\
& {$[0.0118]$} & {$[0.0121]$} & {$[0.0139]$} & {$[0.0196]$} & {$[0.0362]$} & {$[0.0252]$} \\
Artist visibility & 0.0104 & 0.0148 & $-0.130^{* * *}$ & $-0.343^{* *}$ & $-0.312^{*}$ & $-0.0875^{* *}$ \\
& {$[0.0111]$} & {$[0.0112]$} & {$[0.0338]$} & {$[0.135]$} & {$[0.189]$} & {$[0.0436]$} \\
Artist visibility, squared & $-0.0116^{* *}$ & $-0.0134^{* *}$ & 0.0151 & 0.0568 & 0.0578 & 0.00196 \\
& {$[0.00528]$} & {$[0.00528]$} & {$[0.0113]$} & {$[0.0461]$} & {$[0.0632]$} & {$[0.0144]$} \\
First auction & $0.0292^{* * *}$ & $0.0298^{* * *}$ & 0.00668 & $-8.54 \mathrm{E}-05$ & $-0.0313^{* *}$ & $-0.0474^{* * *}$ \\
& {$[0.00841]$} & {$[0.00844]$} & {$[0.00871]$} & {$[0.0102]$} & {$[0.0138]$} & {$[0.0106]$} \\
Market share & $0.230^{* * *}$ & - & $0.223^{* * *}$ & $0.153^{* *}$ & $0.277^{* *}$ & $0.289^{* * *}$ \\
& {$[0.0596]$} & & {$[0.0614]$} & {$[0.0769]$} & {$[0.140]$} & {$[0.0798]$} \\
Multiple & $0.105^{* * *}$ & $0.113^{* * *}$ & $0.101^{* * *}$ & $0.101^{* * *}$ & $0.0713^{* * *}$ & $0.0966^{* * *}$ \\
& {$[0.0232]$} & {$[0.0249]$} & {$[0.0236]$} & {$[0.0258]$} & {$[0.0276]$} & {$[0.0292]$} \\
Observations & 49,573 & 49,558 & 49,573 & 45,095 & 34,669 & 44,445 \\
Adj. $R^{2}$ & 0.103 & 0.109 & 0.128 & 0.155 & 0.192 & 0.158 \\
House F.E. & Yes & No & Yes & Yes & Yes & No \\
Town F.E. & Yes & No & Yes & Yes & No & No \\
Year F.E. & Yes & No & Yes & No & No & Yes \\
House-Town-Year F.E. & No & Yes & No & No & No & No \\
Category F.E. & Yes & Yes & No & No & No & No \\
Artist F.E. & No & No & Yes & No & No & No \\
Artist-Year F.E. & No & No & No & Yes & No & No \\
Artist-Year-Town F.E. & No & No & No & No & Yes & No \\
House-Town-Artist F.E. & No & No & No & No & No & Yes \\
\hline
\end{tabular}


Table 4 (continued)

Panel B. Dependent variable $=$ Distance

\begin{tabular}{lcccccc}
\hline & $(1)$ & $(2)$ & $(3)$ & $(4)$ & $(5)$ & $(6)$ \\
\hline Experience & $-0.0880^{* * *}$ & $-0.0621^{* *}$ & $-0.0869^{* *}$ & $-0.102^{* *}$ & -0.0148 & 0.00828 \\
& {$[0.0340]$} & {$[0.0258]$} & {$[0.0373]$} & {$[0.0461]$} & {$[0.0325]$} & {$[0.0292]$} \\
Artist visibility & $-0.0676^{* * *}$ & $-0.0556^{* *}$ & $-0.167^{* * *}$ & 0.146 & 0.265 & -0.110 \\
& {$[0.0249]$} & {$[0.0247]$} & {$[0.0615]$} & {$[0.207]$} & {$[0.224]$} & {$[0.0715]$} \\
Artist visibility, squared & $0.0217^{*}$ & 0.0140 & $0.0523^{* *}$ & -0.108 & -0.118 & $0.0450^{*}$ \\
& {$[0.0111]$} & {$[0.0112]$} & {$[0.0217]$} & {$[0.0674]$} & {$[0.0762]$} & {$[0.0264]$} \\
First auction & $0.0557^{* * *}$ & $0.0513^{* * *}$ & $0.0485^{* * *}$ & 0.0271 & $0.0339^{* *}$ & $0.0560^{* * *}$ \\
& {$[0.0137]$} & {$[0.0138]$} & {$[0.0157]$} & {$[0.0172]$} & {$[0.0145]$} & {$[0.0202]$} \\
Market share & $0.556^{* * *}$ & - & $0.400^{* * *}$ & 0.281 & $0.567^{* * *}$ & $0.548^{* * *}$ \\
& {$[0.135]$} & & {$[0.133]$} & {$[0.294]$} & {$[0.191]$} & {$[0.145]$} \\
Multiple & $0.146^{* * *}$ & $0.151^{* * *}$ & $0.133^{* * *}$ & $0.121^{* * *}$ & 0.123 & $0.118^{*}$ \\
& {$[0.0480]$} & {$[0.0483]$} & {$[0.0491]$} & {$[0.0462]$} & {$[0.0821]$} & {$[0.0672]$} \\
Observations & 29,039 & 29,025 & 28,950 & 24,736 & 18,066 & 24,794 \\
Adj. ${ }^{2}$ & 0.015 & 0.051 & 0.053 & 0.151 & 0.432 & 0.430 \\
House F.E. & Yes & No & Yes & Yes & Yes & No \\
Town F.E. & Yes & No & Yes & Yes & No & No \\
Year F.E. & Yes & No & Yes & No & No & Yes \\
House-Town-Year F.E. & No & Yes & No & No & No & No \\
Category F.E. & Yes & Yes & No & No & No & No \\
Artist F.E. & No & No & Yes & No & No & No \\
Artist-Year F.E. & No & No & No & Yes & No & No \\
Artist-Year-Town F.E. & No & No & No & No & Yes & No \\
House-Town-Artist F.E. & No & No & No & No & No & Yes \\
\hline & & & & & &
\end{tabular}




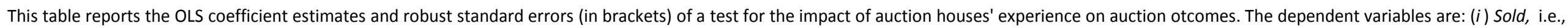

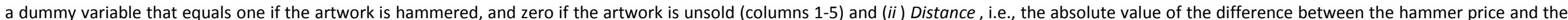

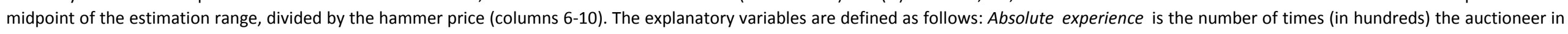

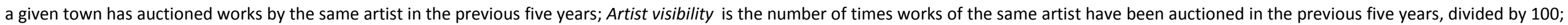

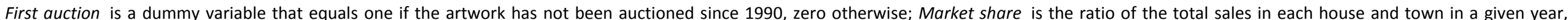

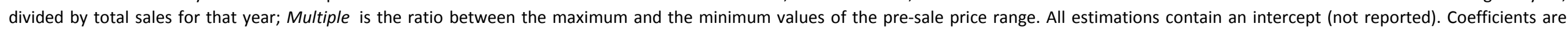
estimated over a sample of Italian paintings put in auction in years 2000-2008.

$* * *, * *$, and $*$ indicate statistical significance at the $1 \%, 5 \%$, and $10 \%$ levels, respectively.

\begin{tabular}{|c|c|c|c|c|c|c|c|c|c|c|}
\hline & \multicolumn{5}{|c|}{ Dependent variable $=$ Sold } & \multicolumn{5}{|c|}{ Dependent variable $=$ Distance } \\
\hline & (1) & (2) & (3) & (4) & (5) & (6) & (7) & (8) & (9) & (10) \\
\hline Absolute experience & $\begin{array}{c}0.0972 * * * \\
{[0.0268]}\end{array}$ & $\begin{array}{c}0.0979 * * * \\
{[0.0271]}\end{array}$ & $\begin{array}{l}0.0548^{*} \\
{[0.0292]}\end{array}$ & $\begin{array}{c}0.0746^{* *} \\
{[0.0343]}\end{array}$ & $\begin{array}{l}0.148 * * \\
{[0.0663]}\end{array}$ & $\begin{array}{c}-0.131^{* * *} \\
{[0.0420]}\end{array}$ & $\begin{array}{c}-0.109 * * * \\
{[0.0368]}\end{array}$ & $\begin{array}{l}-0.122^{* *} \\
{[0.0493]}\end{array}$ & $\begin{array}{c}-0.0764 \\
{[0.0499]}\end{array}$ & $\begin{array}{l}0.00930 \\
{[0.0733]}\end{array}$ \\
\hline Artist visibility & $\begin{array}{l}-0.00675 \\
{[0.0115]}\end{array}$ & $\begin{array}{l}-0.00229 \\
{[0.0115]}\end{array}$ & $\begin{array}{c}-0.140 * * * \\
{[0.0342]}\end{array}$ & $\begin{array}{c}-0.379 * * * \\
{[0.135]}\end{array}$ & $\begin{array}{c}-0.345^{*} \\
{[0.190]}\end{array}$ & $\begin{array}{l}-0.0428 * \\
{[0.0254]}\end{array}$ & $\begin{array}{l}-0.0363 \\
{[0.0252]}\end{array}$ & $\begin{array}{c}-0.145^{* *} \\
{[0.0624]}\end{array}$ & $\begin{array}{c}0.184 \\
{[0.201]}\end{array}$ & $\begin{array}{c}0.263 \\
{[0.218]}\end{array}$ \\
\hline Artist visibility, squared & $\begin{array}{c}-0.0103 * \\
{[0.00527]}\end{array}$ & $\begin{array}{c}-0.0123 * * \\
{[0.00527]}\end{array}$ & $\begin{array}{c}0.0165 \\
{[0.0114]}\end{array}$ & $\begin{array}{c}0.0646 \\
{[0.0462]}\end{array}$ & $\begin{array}{c}0.0627 \\
{[0.0633]}\end{array}$ & $\begin{array}{l}0.0200 * \\
{[0.0109]}\end{array}$ & $\begin{array}{c}0.0132 \\
{[0.0109]}\end{array}$ & $\begin{array}{c}0.0499 * * \\
{[0.0217]}\end{array}$ & $\begin{array}{l}-0.116^{*} \\
{[0.0666]}\end{array}$ & $\begin{array}{c}-0.118 \\
{[0.0763]}\end{array}$ \\
\hline First auction & $\begin{array}{c}0.0275^{* * *} \\
{[0.00838]}\end{array}$ & $\begin{array}{c}0.0281 * * * \\
{[0.00841]}\end{array}$ & $\begin{array}{c}0.00476 \\
{[0.00869]}\end{array}$ & $\begin{array}{c}-0.00291 \\
{[0.0101]}\end{array}$ & $\begin{array}{c}-0.0334^{* *} \\
{[0.0137]}\end{array}$ & $\begin{array}{c}0.0586 * * * \\
{[0.0140]}\end{array}$ & $\begin{array}{c}0.0532 * * * \\
{[0.0140]}\end{array}$ & $\begin{array}{c}0.0512 * * * \\
{[0.0160]}\end{array}$ & $\begin{array}{l}0.0294 * \\
{[0.0171]}\end{array}$ & $\begin{array}{c}0.0342 * * \\
{[0.0144]}\end{array}$ \\
\hline Market share & $\begin{array}{c}0.229 * * * \\
{[0.0596]}\end{array}$ & & $\begin{array}{c}0.225^{* * *} \\
{[0.0614]}\end{array}$ & $\begin{array}{l}0.157^{* *} \\
{[0.0769]}\end{array}$ & $\begin{array}{c}0.285^{* *} \\
{[0.140]}\end{array}$ & $\begin{array}{c}0.558^{* * *} \\
{[0.135]}\end{array}$ & & $\begin{array}{c}0.399 * * * \\
{[0.133]}\end{array}$ & $\begin{array}{c}0.279 \\
{[0.295]}\end{array}$ & $\begin{array}{c}0.565^{* * *} \\
{[0.190]}\end{array}$ \\
\hline Multiple & $\begin{array}{c}0.106 * * * \\
{[0.0233]}\end{array}$ & $\begin{array}{c}0.114^{* * *} \\
{[0.0250]}\end{array}$ & $\begin{array}{c}0.101^{* * *} \\
{[0.0235]}\end{array}$ & $\begin{array}{c}0.101^{* * *} \\
{[0.0257]}\end{array}$ & $\begin{array}{c}0.0713 * * * \\
{[0.0275]}\end{array}$ & $\begin{array}{c}0.145^{* * *} \\
{[0.0481]}\end{array}$ & $\begin{array}{c}0.150 * * * \\
{[0.0483]}\end{array}$ & $\begin{array}{c}0.133 * * * \\
{[0.0493]}\end{array}$ & $\begin{array}{c}0.121^{* * *} \\
{[0.0463]}\end{array}$ & $\begin{array}{c}0.123 \\
{[0.0821]}\end{array}$ \\
\hline Observations & 49,573 & 49,558 & 49,573 & 45,095 & 34,669 & 29,039 & 29,025 & 28,950 & 24,736 & 18,066 \\
\hline Adj. $R^{2}$ & 0.103 & 0.109 & 0.128 & 0.154 & 0.191 & 0.014 & 0.050 & 0.053 & 0.151 & 0.432 \\
\hline House F.E. & Yes & No & Yes & Yes & Yes & Yes & No & Yes & Yes & Yes \\
\hline Town F.E. & Yes & No & Yes & Yes & No & Yes & No & Yes & Yes & No \\
\hline Year F.E. & Yes & No & Yes & No & No & Yes & No & Yes & No & No \\
\hline House-Town-Year F.E. & No & Yes & No & No & No & No & Yes & No & No & No \\
\hline Category F.E. & Yes & Yes & No & No & No & Yes & Yes & No & No & No \\
\hline Artist F.E. & No & No & Yes & No & No & No & No & Yes & No & No \\
\hline Artist-Year F.E. & No & No & No & Yes & No & No & No & No & Yes & No \\
\hline Artist-Town-Year F.E. & No & No & No & No & Yes & No & No & No & No & Yes \\
\hline
\end{tabular}


This table reports the OLS coefficient estimates and robust standard errors (in brackets) of a test for the impact of auction houses' experience on auction otcomes. The dependent variables are: ( $i$ Sold, i.e., a dummy variable that equals one if the artwork is hammered, and zero if the artwork is unsold (columns 1-5) and (ii) Distance, i.e., the absolute value of the difference between the hammer

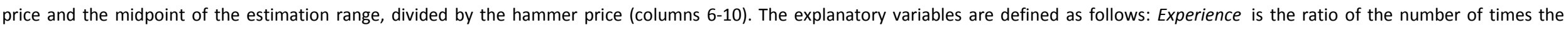
auctioneer in a given town has auctioned works by the artist in the previous five years, to the number of times that works of the same artist have been auctioned in any auction house during the past five years; Artist visibility is the number of times works of the same artist have been auctioned in the previous five years, divided by 100; First auction is a dummy variable that equals one if the artwork has not been auctioned since 1990, zero otherwise; Market share is the ratio of the total sales in each house and town in a given year, divided by total sales for that year; Multiple is the ratio between the maximum and the minimum values of the pre-sale price range. All estimations include an intercept (not reported). Coefficients are estimated over a sample of Italian paintings put in auction in years 2000-2008 with the exclusion of those auctioned by Christie's or Sotheby's.

$* * *, * *$ and $*$ indicate statistical significance at the $1 \%, 5 \%$, and $10 \%$ levels, respectively.

\begin{tabular}{|c|c|c|c|c|c|c|c|c|c|c|}
\hline & \multicolumn{5}{|c|}{ Dependent variable $=$ Sold } & \multicolumn{5}{|c|}{ Dependent variable $=$ Distance } \\
\hline & -1 & $(2)$ & (3) & (4) & (5) & (6) & (7) & (8) & (9) & (10) \\
\hline \multirow[t]{2}{*}{ Experience } & $0.0657 * * *$ & $0.0647 * * *$ & $0.0523 * *$ & $0.129 * * *$ & $0.196 * *$ & $-0.103 * *$ & $-0.0868 * *$ & $-0.0811^{*}$ & -0.138 & -0.0767 \\
\hline & {$[0.0156]$} & {$[0.0160]$} & {$[0.0210]$} & {$[0.0353]$} & {$[0.0913]$} & {$[0.0436]$} & {$[0.0389]$} & {$[0.0447]$} & {$[0.116]$} & [0.113] \\
\hline \multirow[t]{2}{*}{ Artist visibility } & 0.0142 & 0.0225 & $-0.137 * * *$ & $-0.640 * * *$ & $-0.794 * * *$ & -0.0535 & -0.0593 & -0.0743 & -0.0829 & 0.149 \\
\hline & {$[0.0155]$} & {$[0.0155]$} & {$[0.0473]$} & {$[0.190]$} & {$[0.282]$} & [0.0433] & {$[0.0432]$} & {$[0.0988]$} & {$[0.301]$} & {$[0.220]$} \\
\hline \multirow[t]{2}{*}{ Artist visibility, squared } & $-0.0185^{* *}$ & $-0.0221 * * *$ & 0.0148 & $0.140 * *$ & $0.203^{* *}$ & 0.0131 & 0.0183 & 0.0190 & 0.0103 & -0.0469 \\
\hline & [0.00738] & {$[0.00737]$} & [0.0155] & [0.0639] & [0.0922] & [0.0191] & [0.0195] & [0.0309] & [0.0900] & [0.0734] \\
\hline \multirow[t]{2}{*}{ First auction } & $0.0405^{* * *}$ & $0.0414 * * *$ & 0.00517 & 0.000581 & -0.0343 & $0.0429 * *$ & 0.0272 & $0.0535^{*}$ & 0.0327 & 0.00673 \\
\hline & [0.0120] & [0.0120] & [0.0126] & [0.0159] & [0.0227] & [0.0197] & [0.0192] & [0.0296] & [0.0218] & [0.0223] \\
\hline \multirow[t]{2}{*}{ Market share } & $1.088 * * *$ & - & $0.913^{* * *}$ & 0.287 & 1.613 & $0.925^{*}$ & - & 0.732 & 0.923 & -1.748 \\
\hline & [0.291] & & [0.308] & [0.445] & [1.610] & {$[0.505]$} & & [0.617] & [1.875] & [1.328] \\
\hline \multirow[t]{2}{*}{ Multiple } & $0.162 * * *$ & $0.174 * * *$ & $0.153 * * *$ & $0.173 * * *$ & $0.155^{* * *}$ & $0.178 * *$ & $0.173^{* *}$ & $0.184^{* *}$ & $0.242 * *$ & $0.343 * *$ \\
\hline & [0.0379] & {$[0.0416]$} & [0.0390] & [0.0516] & [0.0572] & [0.0796] & [0.0789] & [0.0886] & [0.112] & [0.150] \\
\hline \multirow[t]{2}{*}{ constant } & -0.251 & $0.137 * *$ & $0.397 * * *$ & $0.498 * * *$ & $0.408 * * *$ & 0.00221 & 0.106 & -0.0154 & 0.0380 & -0.180 \\
\hline & [0.289] & [0.0554] & [0.0632] & [0.0971] & [0.129] & {$[0.146]$} & [0.107] & [0.123] & [0.194] & {$[0.213]$} \\
\hline Observations & 25,523 & 25,515 & 25,523 & 23,290 & 17,239 & 13,029 & 13,022 & 12,987 & 11,187 & 7,704 \\
\hline Adj. $R^{2}$ & 0.131 & 0.138 & 0.163 & 0.206 & 0.262 & 0.013 & 0.045 & 0.074 & 0.135 & 0.472 \\
\hline House F.E. & Yes & No & Yes & Yes & Yes & Yes & No & Yes & Yes & Yes \\
\hline Town F.E. & Yes & No & Yes & Yes & No & Yes & No & Yes & Yes & No \\
\hline Year F.E. & Yes & No & Yes & No & No & Yes & No & Yes & No & No \\
\hline House-Town-Year F.E. & No & Yes & No & No & No & No & Yes & No & No & No \\
\hline Category F.E. & Yes & Yes & No & No & No & Yes & Yes & No & No & No \\
\hline Artist F.E. & No & No & Yes & No & No & No & No & Yes & No & No \\
\hline Artist-Year F.E. & No & No & No & Yes & No & No & No & No & Yes & No \\
\hline
\end{tabular}


Table 7. Auction houses' experience and auction outcomes (subsample of Contemporary paintings).

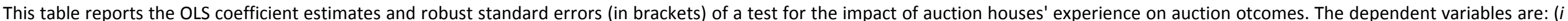

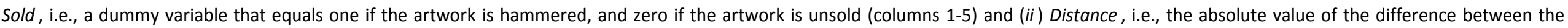

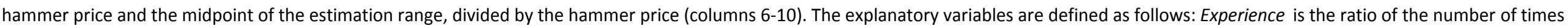

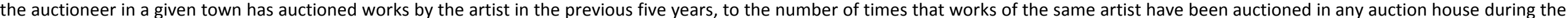

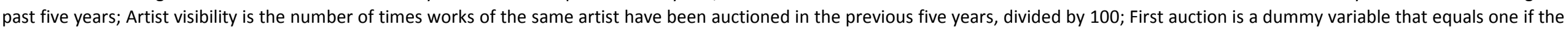

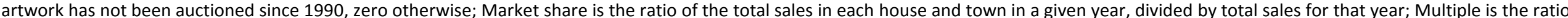

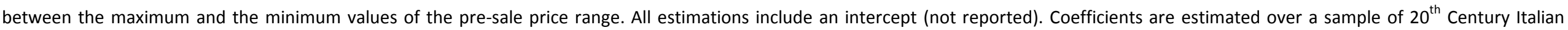
paintings put in auction in years 2000-2008.

$* * *, * *$, and $*$ indicate statistical significance at the $1 \%, 5 \%$, and $10 \%$ levels, respectively.

\begin{tabular}{|c|c|c|c|c|c|c|c|c|c|c|}
\hline & \multicolumn{5}{|c|}{ Dependent variable $=$ Sold } & \multicolumn{5}{|c|}{ Dependent variable $=$ Distance } \\
\hline & (1) & (2) & (3) & (4) & (5) & (6) & (7) & (8) & (9) & (10) \\
\hline Experience & $\begin{array}{c}0.0556^{* * *} \\
{[0.0182]}\end{array}$ & $\begin{array}{c}0.0641 * * * \\
{[0.0187]}\end{array}$ & $\begin{array}{c}0.0540 * * * \\
{[0.0206]}\end{array}$ & $\begin{array}{c}0.118 * * * \\
{[0.0268]}\end{array}$ & $\begin{array}{c}0.163 * * * \\
{[0.0442]}\end{array}$ & $\begin{array}{c}-0.0297^{* *} \\
{[0.0120]}\end{array}$ & $\begin{array}{c}-0.0256 * * \\
{[0.0115]}\end{array}$ & $\begin{array}{c}-0.0351 * * * \\
{[0.0118]}\end{array}$ & $\begin{array}{c}-0.0475^{* * *} \\
{[0.0153]}\end{array}$ & $\begin{array}{c}-0.00464 \\
{[0.0271]}\end{array}$ \\
\hline Artist visibility & $\begin{array}{c}0.0153 \\
{[0.0189]}\end{array}$ & $\begin{array}{l}0.00408 \\
{[0.0192]}\end{array}$ & $\begin{array}{c}-0.163^{* * *} \\
{[0.0488]}\end{array}$ & $\begin{array}{c}-0.147 \\
{[0.163]}\end{array}$ & $\begin{array}{c}-0.174 \\
{[0.202]}\end{array}$ & $\begin{array}{c}-0.0734 * * * \\
{[0.0228]}\end{array}$ & $\begin{array}{c}-0.0730 * * * \\
{[0.0190]}\end{array}$ & $\begin{array}{l}-0.0304 \\
{[0.0259]}\end{array}$ & $\begin{array}{l}-0.0889 \\
{[0.118]}\end{array}$ & $\begin{array}{l}0.0535 \\
{[0.148]}\end{array}$ \\
\hline Artist visibility, squared & $\begin{array}{c}-0.0115 \\
{[0.00829]}\end{array}$ & $\begin{array}{c}-0.00689 \\
{[0.00839]}\end{array}$ & $\begin{array}{c}0.0190 \\
{[0.0168]}\end{array}$ & $\begin{array}{l}-0.00890 \\
{[0.0557]}\end{array}$ & $\begin{array}{l}0.00942 \\
{[0.0668]}\end{array}$ & $\begin{array}{c}0.0191 * * * \\
{[0.00741]}\end{array}$ & $\begin{array}{c}0.0213 * * * \\
{[0.00757]}\end{array}$ & $\begin{array}{c}0.00253 \\
{[0.00893]}\end{array}$ & $\begin{array}{l}-0.0153 \\
{[0.0348]}\end{array}$ & $\begin{array}{c}-0.0334 \\
{[0.0425]}\end{array}$ \\
\hline First auction & $\begin{array}{c}0.0505^{* * *} \\
{[0.0146]}\end{array}$ & $\begin{array}{c}0.0430 * * * \\
{[0.0146]}\end{array}$ & $\begin{array}{c}0.0387^{* * *} \\
{[0.0147]}\end{array}$ & $\begin{array}{c}0.0361 * * \\
{[0.0160]}\end{array}$ & $\begin{array}{c}0.0246 \\
{[0.0187]}\end{array}$ & $\begin{array}{c}0.0307 * * * \\
{[0.00873]}\end{array}$ & $\begin{array}{c}0.0204^{* * *} \\
{[0.00737]}\end{array}$ & $\begin{array}{c}0.0245^{* * *} \\
{[0.00748]}\end{array}$ & $\begin{array}{c}0.0167^{*} \\
{[0.00881]}\end{array}$ & $\begin{array}{c}0.0121 \\
{[0.00905]}\end{array}$ \\
\hline Market share & $\begin{array}{c}0.173 \\
{[0.135]}\end{array}$ & - & $\begin{array}{c}0.213 \\
{[0.137]}\end{array}$ & $\begin{array}{c}0.108 \\
{[0.162]}\end{array}$ & $\begin{array}{l}0.0778 \\
{[0.246]}\end{array}$ & $\begin{array}{c}-0.166 \\
{[0.195]}\end{array}$ & - & $\begin{array}{l}-0.0235 \\
{[0.0907]}\end{array}$ & $\begin{array}{c}0.0162 \\
{[0.0881]}\end{array}$ & $\begin{array}{l}0.0960 \\
{[0.144]}\end{array}$ \\
\hline Multiple & $\begin{array}{l}0.0628^{*} \\
{[0.0356]}\end{array}$ & $\begin{array}{l}0.0720 * \\
{[0.0372]}\end{array}$ & $\begin{array}{l}0.0639 * \\
{[0.0360]}\end{array}$ & $\begin{array}{l}0.0672 * \\
{[0.0347]}\end{array}$ & $\begin{array}{c}0.0355 \\
{[0.0295]}\end{array}$ & $\begin{array}{l}0.108 * * \\
{[0.0439]}\end{array}$ & $\begin{array}{l}0.108 * * \\
{[0.0447]}\end{array}$ & $\begin{array}{c}0.0914 * * \\
{[0.0380]}\end{array}$ & $\begin{array}{c}0.0786 * * \\
{[0.0373]}\end{array}$ & $\begin{array}{l}0.0691 * \\
{[0.0368]}\end{array}$ \\
\hline Observations & 16,341 & 16,336 & 16,341 & 15,625 & 13,883 & 10,959 & 10,951 & 10,947 & 10,189 & 8,833 \\
\hline Adj. $R^{2}$ & 0.103 & 0.116 & 0.144 & 0.188 & 0.220 & 0.041 & 0.151 & 0.274 & 0.507 & 0.500 \\
\hline House F.E. & Yes & No & Yes & Yes & Yes & Yes & No & Yes & Yes & Yes \\
\hline Town F.E. & Yes & No & Yes & Yes & No & Yes & No & Yes & Yes & No \\
\hline Year F.E. & Yes & No & Yes & No & No & Yes & No & Yes & No & No \\
\hline House-Town-Year F.E. & No & Yes & No & No & No & No & Yes & No & No & No \\
\hline Category F.E. & Yes & Yes & No & No & No & Yes & Yes & No & No & No \\
\hline Artist F.E. & No & No & Yes & No & No & No & No & Yes & No & No \\
\hline Artist-Year F.E. & No & No & No & Yes & No & No & No & No & Yes & No \\
\hline Artist-Town-Year F.E. & No & No & No & No & Yes & No & No & No & Yes & Yes \\
\hline
\end{tabular}


Figure 1. Experience valued over different time horizons.

These figures show the OLS point estimates (solid lines) and 95\% confidence intervals (dotted lines) of the coefficients for Experience (T) on Sold (Figure 1.A) and on Distance (Figure 1.B). Experience (T) is defined as the ratio of the number of times the auctioneer in a given town has auctioned works by the artist in the previous $T$ years, to the number of times that works of the same artist have been auctioned in any auction house during the past $T$ years, for values of $T=1,2, \ldots, 10$ on the horizontal axis. Sold is a dummy variable that equals one if the artwork is hammered, and zero if the artwork is unsold. Distance is the absolute value of the difference between the hammer price and the midpoint of the estimation range, divided by the hammer price. All regressions include artist fixed effects, auction house fixed effects, town fixed effects, year fixed effects, a constant term, and the following control variables: Artist visibility $(T)$, i.e., the number of times works of the same artist have been auctioned in the previous T years, divided by 100; Artist visibility (T), squared; First auction, Market share, and Multiple. See Table 4 for definitions of the latter control variables.

Figure 1.A. Coefficients of Experience (T) on regressions for Sold; $T=1,2, \ldots, 10$.

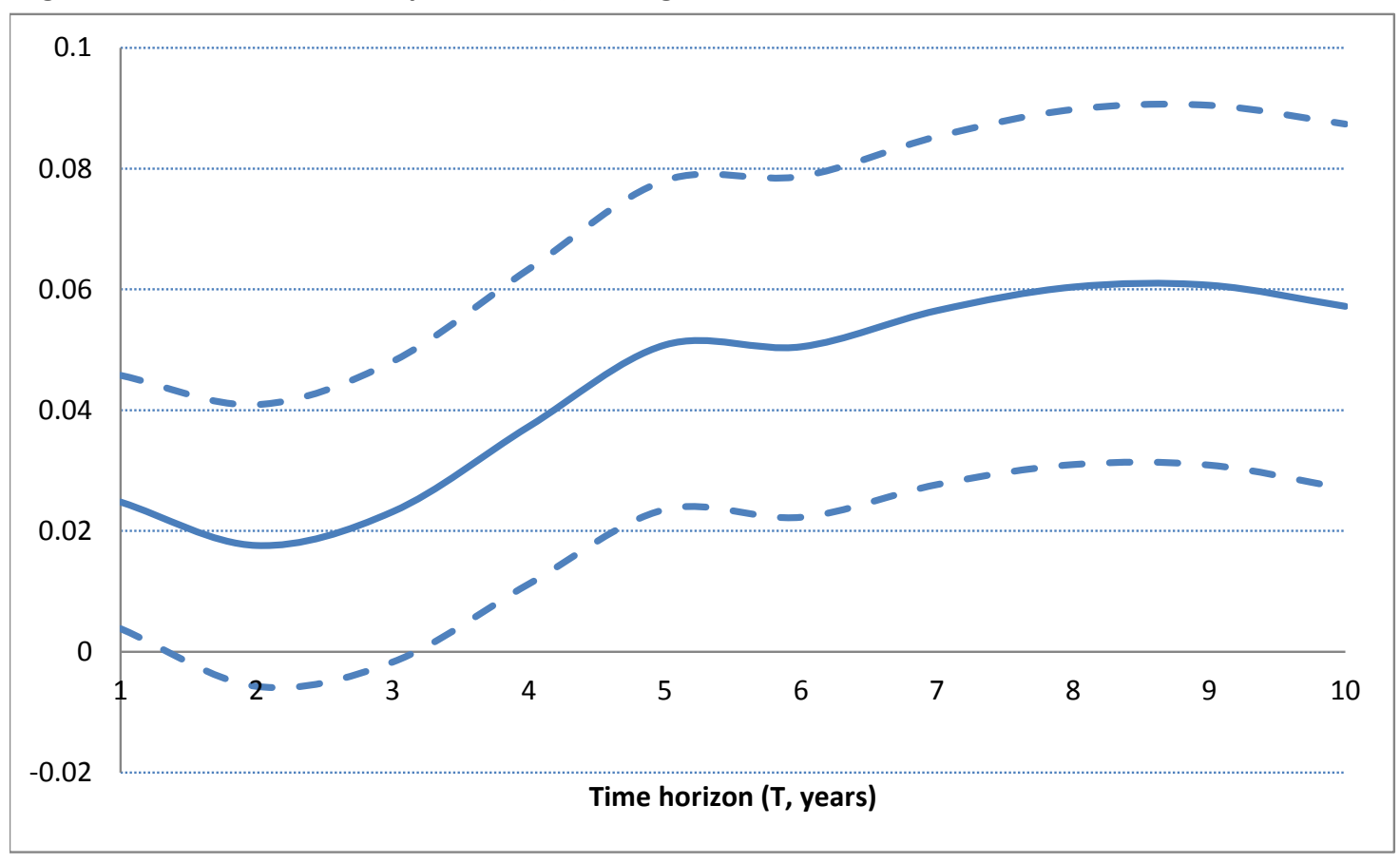

Figure 1.B. Coefficients of Experience $(T)$ in the regressions for Distance; $T=1,2, \ldots, 10$.

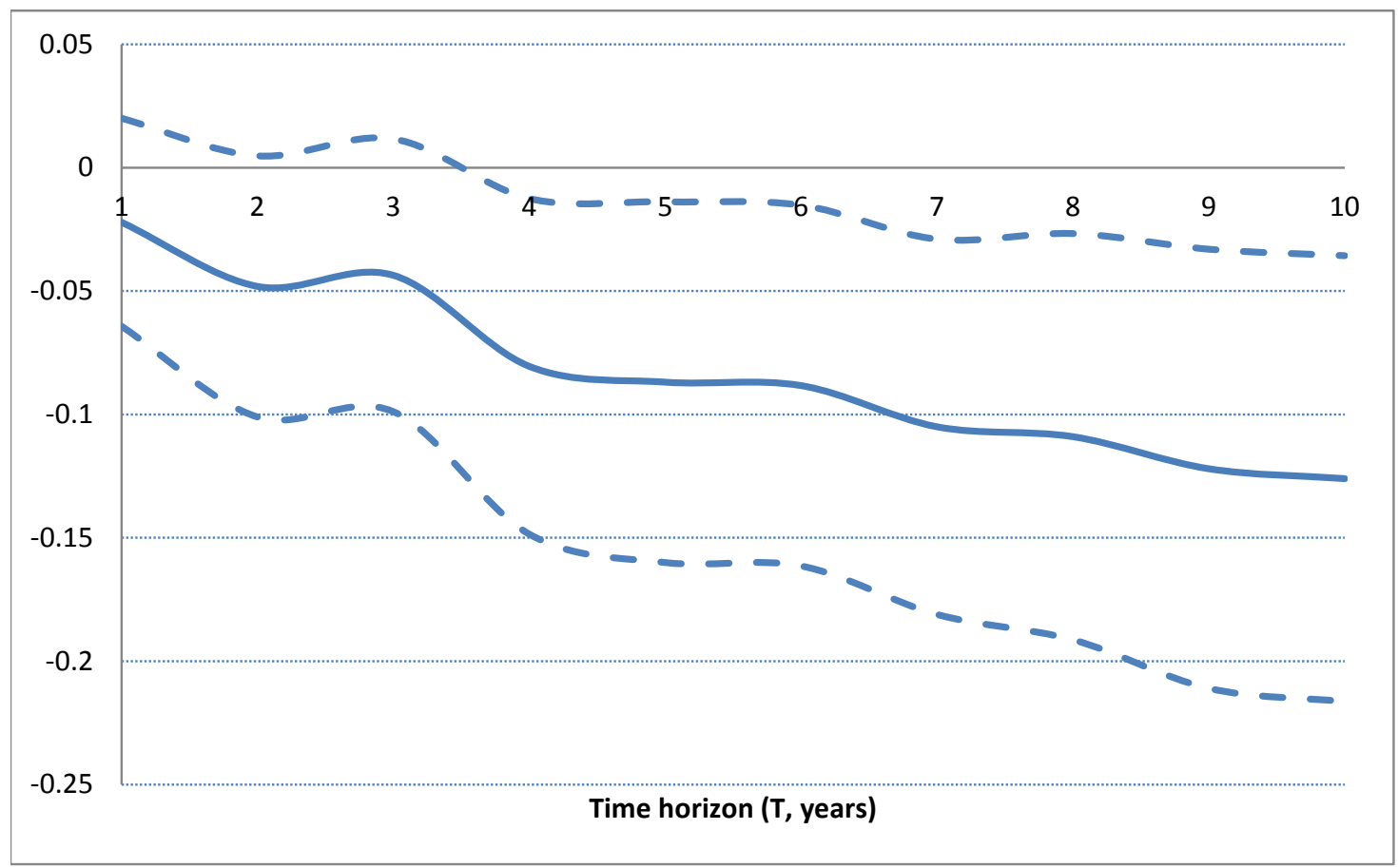




\section{Appendix}

Table A.1. Example of variation in experience within auction house and town for Lucio Fontana's paintings (selected auction houses and towns).

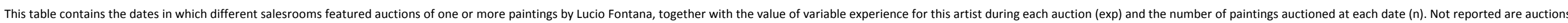

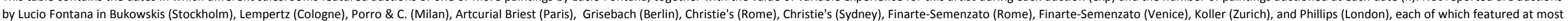
four auctions with paintings of Lucio Fontana.

\begin{tabular}{|c|c|c|c|c|c|c|c|c|c|c|c|c|c|c|c|c|c|c|c|c|c|c|c|c|c|c|}
\hline \multicolumn{3}{|c|}{ Christie's London } & \multicolumn{3}{|c|}{ Sotheby's London } & \multicolumn{3}{|c|}{ Sotheby's Milan } & \multicolumn{3}{|c|}{ Finarte-Semenzato Milan } & \multicolumn{3}{|c|}{ Christie's Milan } & \multicolumn{3}{|c|}{ Christie's New York } & \multicolumn{3}{|c|}{ Sotheby's New York } & \multicolumn{3}{|c|}{ Phillips New York } & \multicolumn{3}{|c|}{ Farsetti Arte Prato } \\
\hline Date & Exp & $n$ & Date & Exp & $\mathrm{n}$ & Date & Exp & $\mathrm{n}$ & Date & Exp & $\mathrm{n}$ & Date & Exp & $\mathrm{n}$ & Date & Exp & $\mathrm{n}$ & Date & Exp & $\mathrm{n}$ & Date & Exp & $\mathrm{n}$ & Date & Exp & $\mathrm{n}$ \\
\hline 28-Jun-00 & 0.278 & 2 & 29-Jun-00 & 0.365 & 4 & 29-Мay-00 & 0.134 & 3 & 11-Apr-00 & 0.099 & 3 & 28-Nov-00 & 0.045 & 2 & $15-$ Nov-00 & 0.009 & 1 & 16-May-01 & 0.005 & 1 & 15-May-01 & 0.000 & 1 & 02-Dec-06 & 0.000 & 3 \\
\hline 06-Dec-00 & 0.278 & 5 & 30-Jun-00 & 0.365 & 2 & 21-Nov-00 & 0.150 & 3 & 12-Dec-00 & 0.099 & 2 & 26-May-01 & 0.054 & 1 & 16-May-01 & 0.014 & 1 & 15-Nov-01 & 0.009 & 1 & 12-Nov-01 & 0.004 & 2 & 25-Мay-07 & 0.013 & 1 \\
\hline 07-Feb-01 & 0.280 & 4 & $25-$ Oct- 00 & 0.378 & 3 & 30-May-01 & 0.149 & 4 & 31-May-01 & 0.091 & 1 & 21-May-02 & 0.048 & 1 & 14-Nov-01 & 0.017 & 1 & 16-May-02 & 0.013 & 1 & 15-May-03 & 0.013 & 1 & 26-Мay-07 & 0.013 & 5 \\
\hline 08-Feb-01 & 0.280 & 2 & 07-Feb-01 & 0.362 & 4 & 27-Nov-01 & 0.140 & 2 & 19-Nov-02 & 0.057 & 1 & 26-May-03 & 0.044 & 2 & 10-Nov-04 & 0.013 & 1 & 13-May-04 & 0.013 & 1 & 12-May-05 & 0.018 & 1 & 30-Nov-07 & 0.033 & 1 \\
\hline 25-Jun-01 & 0.281 & 3 & 27-Jun-01 & 0.367 & 5 & 20-May-02 & 0.140 & 1 & 04-Dec-02 & 0.061 & 3 & 24-Nov-03 & 0.053 & 3 & 11-Nov-04 & 0.013 & 1 & 10-Nov-04 & 0.018 & 1 & 11-May-06 & 0.022 & 1 & 01-Dec-07 & 0.033 & 4 \\
\hline 28-Jun-01 & 0.281 & 5 & 28-Jun-01 & 0.367 & 6 & 26-Nov-02 & 0.134 & 6 & 16-Mar-04 & 0.052 & 2 & 24-May-04 & 0.044 & 1 & $12-$ May-05 & 0.023 & 1 & 11-May-06 & 0.022 & 1 & & & & & & \\
\hline 23-Oct-01 & 0.289 & 5 & 22-Oct-01 & 0.368 & 3 & $27-$ May-03 & 0.142 & 4 & 22-Mar-05 & 0.054 & 1 & 22-Nov-04 & 0.048 & 1 & 09-Nov-05 & 0.026 & 1 & & & & & & & & & \\
\hline 06-Feb-02 & 0.283 & 1 & 23-Oct-01 & 0.368 & 1 & 25-Nov-03 & 0.159 & 3 & 11-Oct-05 & 0.044 & 1 & 23-May-06 & 0.039 & 2 & 09-Мау-06 & 0.027 & 1 & & & & & & & & & \\
\hline 07-Feb-02 & 0.283 & 4 & $07-$ Feb-02 & 0.377 & 4 & 25 -May-04 & 0.159 & 5 & 13-Dec-05 & 0.047 & 1 & 28-Nov-06 & 0.044 & 1 & 10-May-06 & 0.027 & 1 & & & & & & & & & \\
\hline 27-Jun-02 & 0.290 & 3 & 08-Feb-02 & 0.377 & 1 & 23-Nov-04 & 0.157 & 4 & 14-Mar-06 & 0.045 & 3 & 21 -May-07 & 0.047 & 3 & 16-Nov-06 & 0.031 & 1 & & & & & & & & & \\
\hline 28-Jun-02 & 0.290 & 3 & 26-Jun-02 & 0.379 & 2 & 26-Мay-05 & 0.157 & 6 & 19-Dec-06 & 0.053 & 3 & $27-$ Nov-07 & 0.048 & 1 & $16-$ May-07 & 0.030 & 1 & & & & & & & & & \\
\hline 22-Oct-02 & 0.283 & 4 & 27-Jun-02 & 0.379 & 1 & 22-Nov-05 & 0.162 & 2 & 15 -Мay-07 & 0.064 & 2 & 26-Мay-08 & 0.051 & 2 & 17-May-07 & 0.030 & 1 & & & & & & & & & \\
\hline 06-Feb-03 & 0.278 & 1 & 21-Oct-02 & 0.375 & 5 & 24-Мay-06 & 0.162 & 4 & 18-Dec-07 & 0.049 & 2 & & & & & & & & & & & & & & & \\
\hline 26-Jun-03 & 0.266 & 1 & $22-0 c t-02$ & 0.375 & 1 & 21-Nov-06 & 0.166 & 3 & 20-May-08 & 0.055 & 1 & & & & & & & & & & & & & & & \\
\hline 27-Jun-03 & 0.266 & 1 & 06-Feb-03 & 0.359 & 2 & $22-$ Мау-07 & 0.160 & 5 & & & & & & & & & & & & & & & & & & \\
\hline 21-Oct-03 & 0.260 & 6 & 07-Feb-03 & 0.359 & 2 & 26-Nov-07 & 0.157 & 5 & & & & & & & & & & & & & & & & & & \\
\hline 04-Feb-04 & 0.268 & 3 & 25-Jun-03 & 0.349 & 3 & 27-May-08 & 0.150 & 7 & & & & & & & & & & & & & & & & & & \\
\hline
\end{tabular}

